\title{
Socio-Economic and Environmental Impacts of Biomass Valorisation: A Strategic Drive for Sustainable Bioeconomy
}

\author{
Ishtiaq Ahmed 1,*(D), Muhammad Anjum Zia ${ }^{2}$, Huma Afzal ${ }^{2}$, Shaheez Ahmed ${ }^{2}$, Muhammad Ahmad ${ }^{3(\mathbb{C},}$ \\ Zain Akram ${ }^{1}\left(\mathbb{D}\right.$, Farooq Sher ${ }^{4, *}$ ) and Hafiz M. N. Iqbal ${ }^{5, *} \mathbb{D}$
}

1 Gold Coast Campus, Menzies Health Institute Queensland, School of Medical Science, Griffith University, Gold Coast, QLD 4222, Australia; zain.akram@griffithuni.edu.au

2 Enzyme Biotechnology Lab, Department of Biochemistry, University of Agriculture, Faisalabad 38040, Pakistan; rmazia@hotmail.com (M.A.Z.); bc786huma@gmail.com (H.A.); Shaheez.ahmad@gmail.com (S.A.)

3 Shaheed Benazir Bhutto University of Veterinary and Animal Sciences (SBBUVAS), Sakrand 67210, Pakistan; mahmad118@yahoo.com

4 Faculty of Engineering, Environment and Computing, School of Mechanical, Aerospace and Automotive Engineering, Coventry University, Coventry CV1 5FB, UK

5 Tecnologico de Monterrey, School of Engineering and Sciences, Monterrey 64849, Mexico

* Correspondence: ishtiaq.ahmed@griffithuni.edu.au (I.A.); Farooq.Sher@coventry.ac.uk (F.S.); hafiz.iqbal@tec.mx (H.M.N.I.)

check for updates

Citation: Ahmed, I.; Zia, M.A.; Afzal, H.; Ahmed, S.; Ahmad, M.; Akram,

\section{Z.; Sher, F.; Iqbal, H.M.N}

Socio-Economic and Environmental Impacts of Biomass Valorisation: A Strategic Drive for Sustainable Bioeconomy. Sustainability 2021, 13, 4200. https://doi.org/10.3390/ su13084200

Academic Editors: Elena Cristina Rada and Vincenzo Torretta

Received: 11 February 2021

Accepted: 2 April 2021

Published: 9 April 2021

Publisher's Note: MDPI stays neutral with regard to jurisdictional claims in published maps and institutional affiliations.

Copyright: (c) 2021 by the authors. Licensee MDPI, Basel, Switzerland. This article is an open access article distributed under the terms and conditions of the Creative Commons Attribution (CC BY) license (https:/ / creativecommons.org/licenses/by/ $4.0 /)$.
Abstract: In the late twentieth century, the only cost-effective opportunity for waste removal cost at least several thousand dollars, but nowadays, a lot of improvement has occurred. The biomass and waste generation problems attracted concerned authorities to identify and provide environmentally friendly sustainable solutions that possess environmental and economic benefits. The present study emphasises the valorisation of biomass and waste produced by domestic and industrial sectors. Therefore, substantial research is ongoing to replace the traditional treatment methods that potentially acquire less detrimental effects. Synthetic biology can be a unique platform that invites all the relevant characters for designing and assembling an efficient program that could be useful to handle the increasing threat for human beings. In the future, these engineered methods will not only revolutionise our lives but practically lead us to get cheaper biofuels, producing bioenergy, pharmaceutics, and various biochemicals. The bioaugmentation approach concomitant with microbial fuel cells (MFC) is an example that is used to produce electricity from municipal waste, which is directly associated with the loading of waste. Beyond the traditional opportunities, herein, we have spotlighted the new advances in pertinent technology closely related to production and reduction approaches. Various integrated modern techniques and aspects related to the industrial sector are also discussed with suitable examples, including green energy and other industrially relevant products. However, many problems persist in present-day technology that requires essential efforts to handle thoroughly because significant valorisation of biomass and waste involves integrated methods for timely detection, classification, and separation. We reviewed and proposed the anticipated dispensation methods to overcome the growing stream of biomass and waste at a distinct and organisational scale.

Keywords: waste to value; bio-residues; bioconversion; renewable; bioenergy; biodiesel; bioactive compounds; polyhydroxyalkanoates (PHAs)

\section{Introduction}

In the 21st century, it has become challenging to provide clean, affordable, and reliable energy sources, which are very important from the socio-economic and environmental perspectives. To manage these crucial problems, biomass is the most favourable renewable source at the moment [1]. Biomass has drawn attention in the latest years as the only 
continuous carbon source available on earth. Therefore, it is regarded as a perfect substitute for fossil fuels. The use of biomass is a modern approach for power generation and is considered an excellent neutral resource where $\mathrm{CO}_{2}$ emissions are reduced. Biomass is an attractive feedstock due to several reasons. Firstly, it reduces greenhouse gas (GHG) emissions and is a new source, which will be established in the future. Lastly, it has the benefit of providing economic benefits to society. However, biomass possesses an adverse effect when utilised in conventional stoves. It emits polycyclic aromatic hydrocarbons (PAHs). PAHs are composed of more than 100 chemicals that include furans (which are toxic to health either inhaled or ingested), volatile organic compounds, and heavy metals [2,3]. Biomass consists of diverse organic materials which contain chemical energy. Green plants generate this chemical energy by photosynthesis, where sunlight serves as an energy source [4]. Figure 1 illustrates the derived carriers of the resultant energy. These carriers utilise biomass and fix $\mathrm{CO}_{2}$ (i.e., photosynthesis) with a concurrent transformation of solar energy into chemical energy.

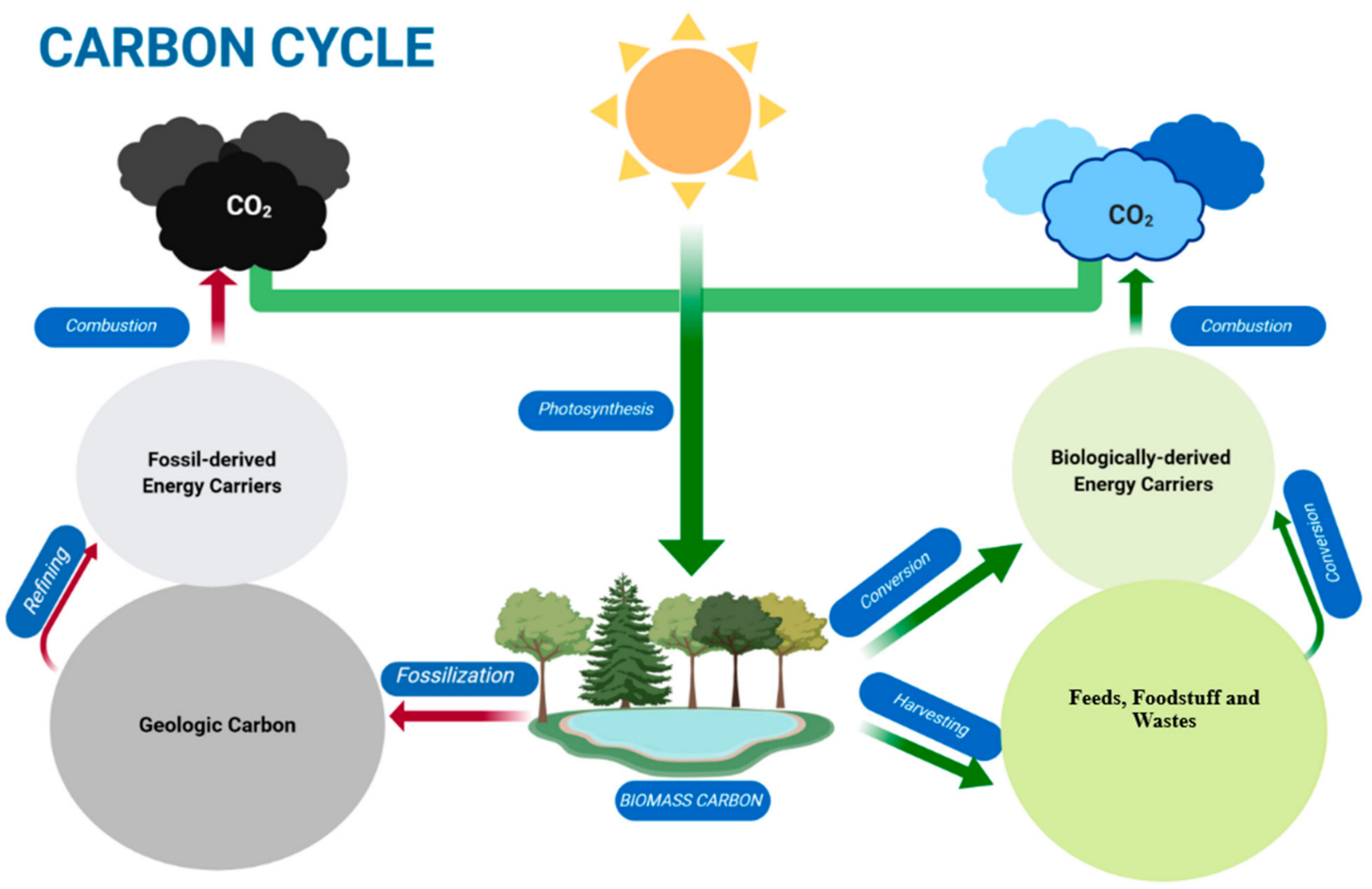

Figure 1. Model of carbon cycle illustrating how energy carriers are derived from biomass. Biomass carbon is generated via photosynthesis upon fixing atmospheric $\mathrm{CO}_{2}$ with the simultaneous conversion of solar energy into chemical energy stored in biomass. Biomass carbon could be transformed into several energy carriers through either an environmentally amicable route (shown in green) or an environmentally unfriendly route (shown in red). If biomass carbon, harvested crops, or wastes are converted into fuel, the process is renewable with no atmospheric $\mathrm{CO}_{2}$ build-up. Conversely, biomass decomposed over several epochs (geologic carbon) can also be partially recovered and utilised. However, the later process is slow, non-sustainable, and potentially harmful to the natural environment.

Biomass, if not used for alternate energy sources, may lead to severe hazards to the environment in the form of discarded materials like waste, which has become a striking and crucial problem of civilised human societies $[5,6]$. In the US, people throw away the waste/garbage equivalent to their body weight on a monthly basis where a significant part of discarded material is composted or recycled and/or incinerated or landfilled. Waste production has increased ten-fold because of the affluent and urban population of the 
world, which will double by 2025. Dealing with waste is one of the most critical issues in developing countries, resulting in increased municipal budgets [7]. Landfills like Laogang (China), Bordo Poniente (Mexico), and Jardim Gramacho (Brazil) are competing for the name of the biggest dump in the world. The urbanisation of the world's population increases solid-waste generation around the globe. It is hard to predict the expanding socio-economic trends leading towards the 22nd century. We are putting our efforts to avoid the maximum rate of waste production in this century. Our efforts will be in vain until we decrease people's growth and the rate of consumption material, otherwise, the world will have to bear a growing problem of waste [8].

\section{Transformation of Biomass and Waste into Bioproducts}

The transformation of biomass into biofuels and chemicals increases worldwide moderate energy sources and reduces global warming [9]. Biomass is a neutral resource of renewable energy and generally burns cleaner than fossil fuels [10-13]. Different biomass forms are converted into fuels and chemicals, like wood and timber waste, plants in agriculture, industrial waste, sludge, and waste from food processing. In contrast, wood logs can be used directly. Wood waste is easily recycled and used as fertilizer as sawmill residues, slashed from logging and municipal wood waste by most plants and crops [12].

It is possible to use various procedures to transform biomass into energy and other industrially relevant high-interest products (Figure 2) [13-15]. Biomass can be converted into fuel, biogas, bioethanol, biodiesel, or changed into syngas [16,17]. Bio-refinery, where several significant processes are integrated and joined with downstream upgrades and cultured separations, will be very attractive to get the most out of feed use and product value [18]. The production of biofuels and chemicals by transforming biomass is becoming popular worldwide to expand energy resources and mitigate global warming. The following characteristics, such as renewable natural sources and carbon-neutral sources, underpin the significance of the biomass. Moreover, resultant fuels acquired from biomass are an important source of sustainable energy because they burn cleanly compared to fossil fuels. Evaluations of the estimated contribution to global energy (i.e., biomass) range from a minimum of $100 \mathrm{EJ} /$ year to a maximum of $400 \mathrm{EJ} /$ year [9]. For example, the total consumption of energy in the USA is around $100 \mathrm{EJ} /$ year and, in 2005, the global commercial consumption of energy was $440 \mathrm{EJ} /$ year. Primary sources of this energy were hydroelectricity, natural gas, oil, coal, and nuclear energy [19]. This means that biomass could contribute between $20 \%$ and $90 \%$ of world energy demand. 


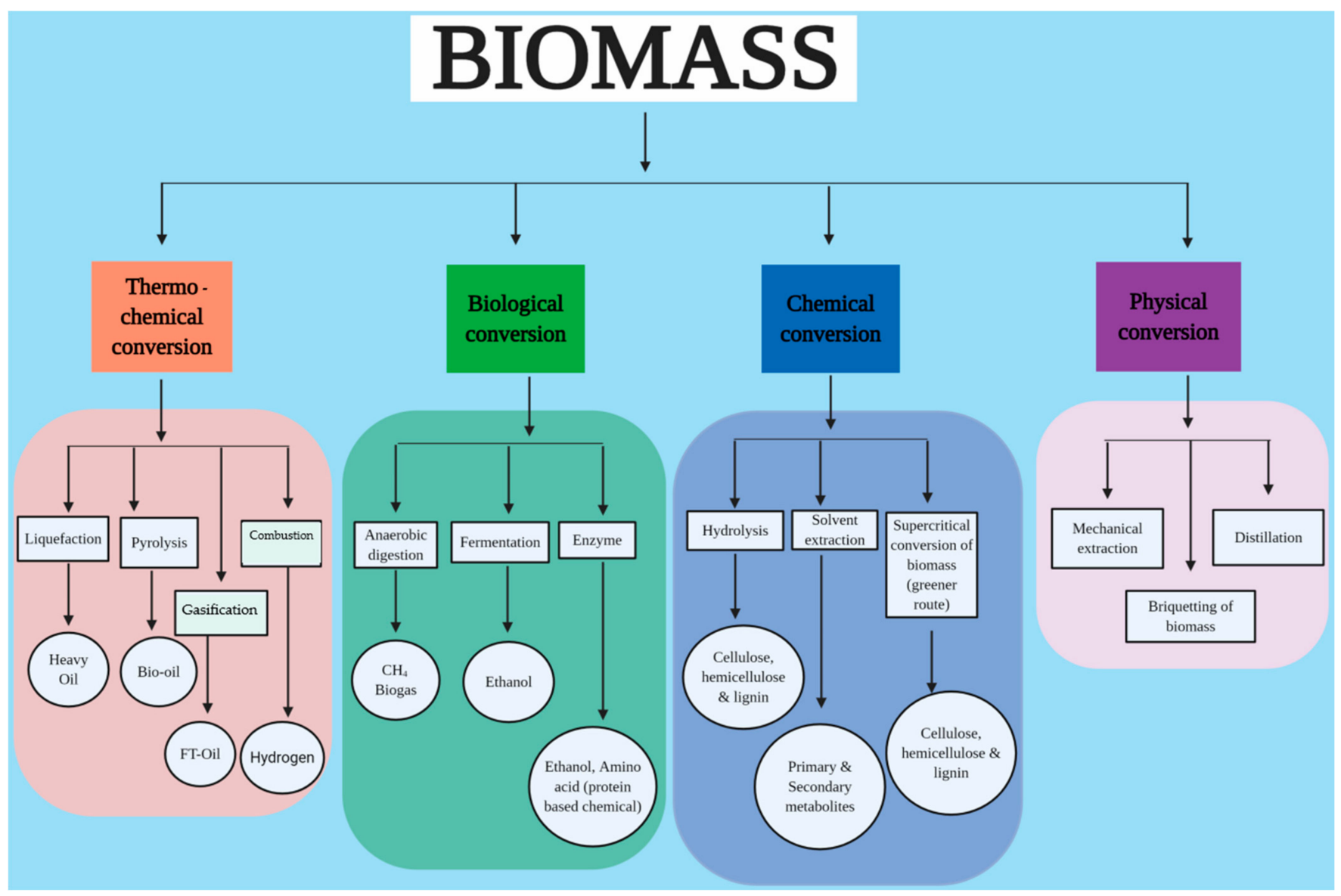

Figure 2. The biomass conversion process and their resulted products of industrial interest.

\section{Sources of Waste/Production of Biomass}

\subsection{Agricultural Aspects}

In agricultural production systems, large quantities of harvested crop residues are generated. The cultivation of wheat, rice, vegetables, fruits, and other crops creates substantial amounts of residues essential for the yearly production of biomass. Therefore, biomass produced from agriculture significantly enhances the generation of sustainable energy used in the industry and the domestic processes [15,20-22]. Unused biomass from agricultural sources can be split into two categories: (1) parts of the plant kept in the field, (2) loss of plant components owing to harvesting techniques. However, all types of residues could not be used for biomass in the past. Nowadays, such biomass residues can be used for many purposes like biofuels (biogas/bioethanol) or energy production and forage, which contribute significantly to a country's economic growth [23-25]. In horticulture, fruit plants, particularly drupes, have endocarp tissues. A drupe fruit's endocarp is the hard and uneatable portion of the fruit, whereas the eatable part is mesocarp. The woody biomass of drupe endocarp is the leading lignin source that usually generates 50 percent of the total [26-28]. Lignin has a greater energy density than cellulose as a biofuel. Lignin plays an essential role in energy production by using endocarp of fruits in horticulture [29-31]. Lignin degradation and the function of the pre-treatment are graphically represented in Figure 3. 


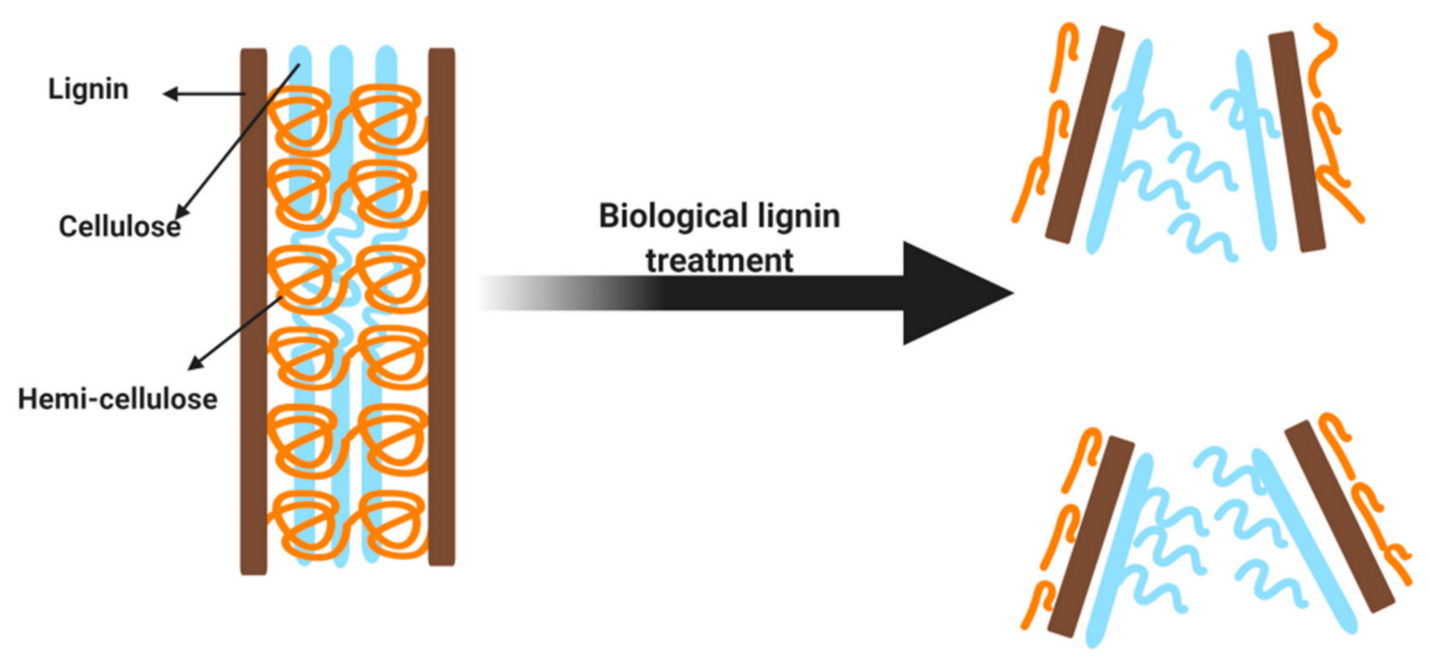

Figure 3. Schematic of the role of biological pre-treatment in biomass lignin degradation. The initial step of lignin biodegradation is when the oxidative enzymes induce new functional groups into lignin's macromolecular structure, making lignin vulnerable to other enzymes' consequent degradation. The natural form of lignin has numerous different functional groups that could be specifically functionalized.

\subsection{Industrial Aspects}

Microorganisms can be used for biomass production in industry. Particularly yeast which serves as biocatalysts and used in bakeries, lactic acid (used as starter culture in manufacturing of dairy products), breweries, probiotics, aqua and animal feed production [32,33]. On a large scale, fermentation can be used with economical substrates and products for biomass production. These economical substrates include soya bean meal, sugar cane molasses, and various industries' wastes [34-36]. Solid biomass is preferred to use in the industry. Liquid waste and biogas are also used in industrial applications, but particularly solid biomass is important for the past 7 years. In other countries, 80 percent of the global biomass has significant application in industry. Most of the industry's biomass is obtained from forests in the United States and mostly black liquor [1]. In Sweden, 41 percent of the industries consumed biomass in 2010. The Finnish timber processing sector accounted for 54 percent of total industrial power consumption in 2010. In particular, wood-based biomass is used by the wood processing sector, which accounted for 45 percent of total industrial power use in 2010.

\subsection{Domestic Food Waste and Considerations}

Economic growth is facing pivotal problems worldwide due to increased waste products that cause energy loss, damage to the environment and human health, and adversely affect quality of life [37,38]. The European Union's goal to discover an effective source for the "Recycling Society" can be a better resource to prevent waste generation. Biological waste is the most significant portion of municipal solid waste (MSW), primarily food waste $[39,40]$. As a result, the rise in the population increased the utilisation of food, and the production of waste (i.e., food waste) is also expected to increase substantially. Food waste is primarily controlled at the EU level by the Waste Framework Directive [41]. Therefore, it is evident that efficient and alternative methods of handling biodegradable waste generated in homes need to be found $[36,42,43]$. Domestic composting and anaerobic digestion are both familiar, distributed, and compact processes. Still, they fail many times and cause more problems than fixing them, such as odours and greenhouse gas (GHG) emissions [44,45]. Approximately $23 \%$ of the 4.8 million tons of municipal solid waste produced yearly are reused (mostly waste from packaging), however, the remaining $77 \%$ are disposed of without proper treatment. In the shortage of new innovative projects, the proportion of produced waste is expected to increase continuously with severe environmental issues in the foreseeable future. 


\section{Characteristics and Composition of Biomass}

There is a broad range of produced biomass, thereby there are significant variations in the composition of industrial or domestically generated biomass. Cellulose, hemicelluloses, lignin, starch, and proteins are some of the main elements [46-49]. Cellulose: A polysaccharide where $\beta$-glucoside bonds evenly connect $\mathrm{D}_{\text {-glucose. Organic compound cellulose }}$ is an important component in the primary cell wall of the plants. It supports the structural assembly of the cell wall $[50,51]$. Cellulose assembles into unbranched and long micro fibrils that provide supports. Several bacterial species secrete cellulose to facilitate biofilm formation [52]. Its molecular formula is $\left(\mathrm{C}_{6} \mathrm{H}_{10} \mathrm{O}_{5}\right)_{n}$. The polymerisation degree stated by $\mathrm{n}$ is broad, ranging from thousands to many tens of thousands. A schematic illustration of plant cellulose is given in Figure 4. Hemicellulose: Hemicellulose comprises several heteropolymers. It is a polysaccharide with 5-carbon monosaccharide units including D-xylose, D-arabinose, and 6-carbon monosaccharide units which have $\mathrm{D}^{-}$-Galactose, $\mathrm{D}^{-}$ glucose, and $\mathrm{D}^{-}$-mannose. Hemicellulose possesses a lower molecular weight than cellulose and has a less specialised structure than cellulose [53-55]. Hemicellulose is known as a second main component of the biomass from the plant. The industrial use of hemicellulose has expanded with time and the integration of modern techniques into the existing methods. Lignin: A compound whose constituent units, phenyl-propane, and its derivatives are 3-dimensionally linked. Cellulose, hemicelluloses, and lignin are widely discovered in many types of biomass [55]. A network of irregular polymers that consists of cellulose and hemicellulose fibres is recognised as lignin. The said network provides structural support to the plants. The irregular formation and complex structural identity make its exploitation challenging in the industry sector. The complex structure is impervious to most of the chemical and hydrolysis treatment methods. Plant biomass chemical composition differs between species. Generally, crops are comprised of about 25 percent lignin and 75 percent carbohydrates. The percentage of carbohydrates is composed of many sugar molecules in the form of polymers. There are two distinctive categories: cellulose and hemicellulose. The moisture content is considered the most significant property of biomass feedstock. The moisture content negatively affects the fuel's energy when used for incineration and other processes (e.g., thermo-chemical) $[13,14]$. Dry biomass has a higher heating value because it utilises little energy to evaporate any moisture. There is a direct association between the energy ratio and humidity, an increase in humidity entails less energy $[14,56,57]$. Biomass materials contain a certain amount of humidity, from $10 \%$ for a dried straw to over $50 \%$ for new cut timber [58].

Carbon: Biomass carbon content is around $45 \%$, while coal has $60 \%$ or higher. A greater carbon content results in a higher heating value [58]. Hydrogen: Biomass hydrogen content is about $6 \%$ [59]. A greater content of hydrogen results in a greater value of heating. Nitrogen: Biomass nitrogen content ranges from 0.2 percent to over 1 percent [59]. Fuelbound nitrogen is responsible for most emissions from the biomass combustion of nitrogen oxide (NOx). Lower nitrogen content should result in reduced emissions of NOx in the fuel (e.g., diesel). Sulphur: Biomass fuels have a sulphur content of less than 0.2 percent, with a few exceptions as elevated as $0.5-0.7$ percent. Coals range from 0.5 percent to 0.75 percent [58]. Chloride: Biomass combustion with elevated levels of chloride may result in enhanced fouling of ash. The boiler tubes' high chloride content results in hydrochloric acid formation, leading to corrosion resulting in pipe failure and water leakage in the boiler. 


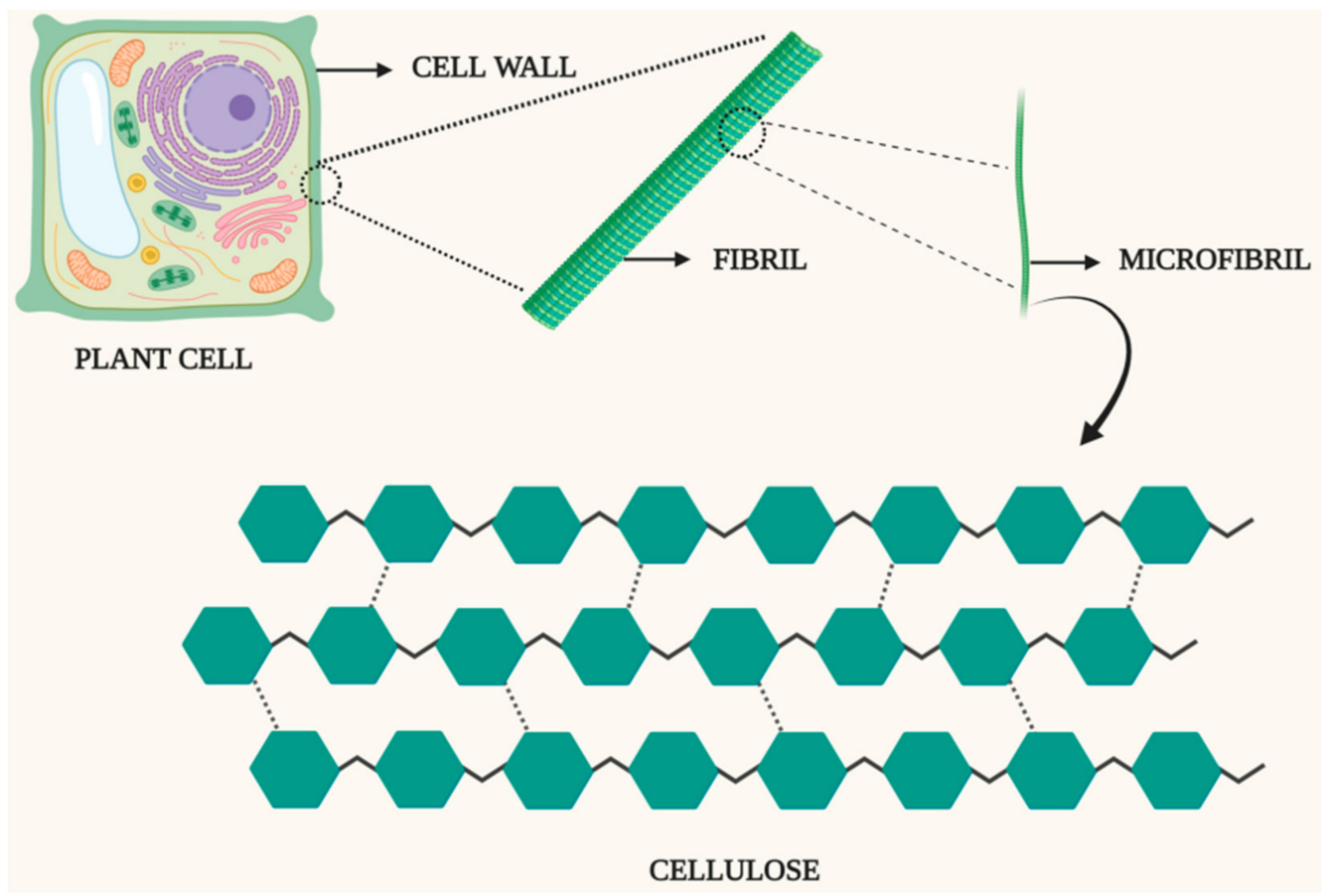

Figure 4. Schematic illustration of plant cellulose.

\section{Green Technologies for Biomass and Waste Valorisation}

Waste valorisation is a process that converts waste materials into valuable products like chemicals, fuels, and materials. The waste valorisation concept relies on the thought; the waste products contain unused polymeric products that can convert into energy and different forms of chemicals $[60,61]$. These types of products make the waste residues a valuable source that could not be left unharnessed. This idea can be applied to artificial waste or bio-waste, and it will become the basis of the waste-to-energy approach. Waste valorisation is not magnificent because of the deletion of natural resources, but it is muchneeded technology for waste management and renewable energy production and also produces high values of nano-bioplastic products and ethanol, which are cost-effective and sustainable [62]. Figure 5 illustrates a graphical representation of green technologies applied for biomass and waste valorisation.

In this context, waste-to-value ( $\mathrm{WtV})$ and, more specifically, waste-to-energy (WtE) have noteworthy potential that should be considered in future considerations prior to the development and implementation of tools like Life Cycle Assessment (LCA), Ecological Indicators (EI), and/or Ecological Footprint Analysis (EFA) [63,64]. Using WtV and/or $\mathrm{WtE}$ thematic concepts with a zero-waste approach, fine chemicals and/or valuable energy are produced from waste residues using processes, such as green processing technologies, using organic and inorganic chemicals, genetically engineered organisms, and others. Other technological WtE solutions, such as anaerobic digestion, incineration, gasification, pyrolysis, landfill waste, and agro-industrial waste biomass residues to bioenergy, are considered valuable drivers to optimise the waste supply chain management to strengthens the modern WtE facilities [64]. Some of the technological and in practice strategies are taken as model examples and thus are discussed in the following subsections. 


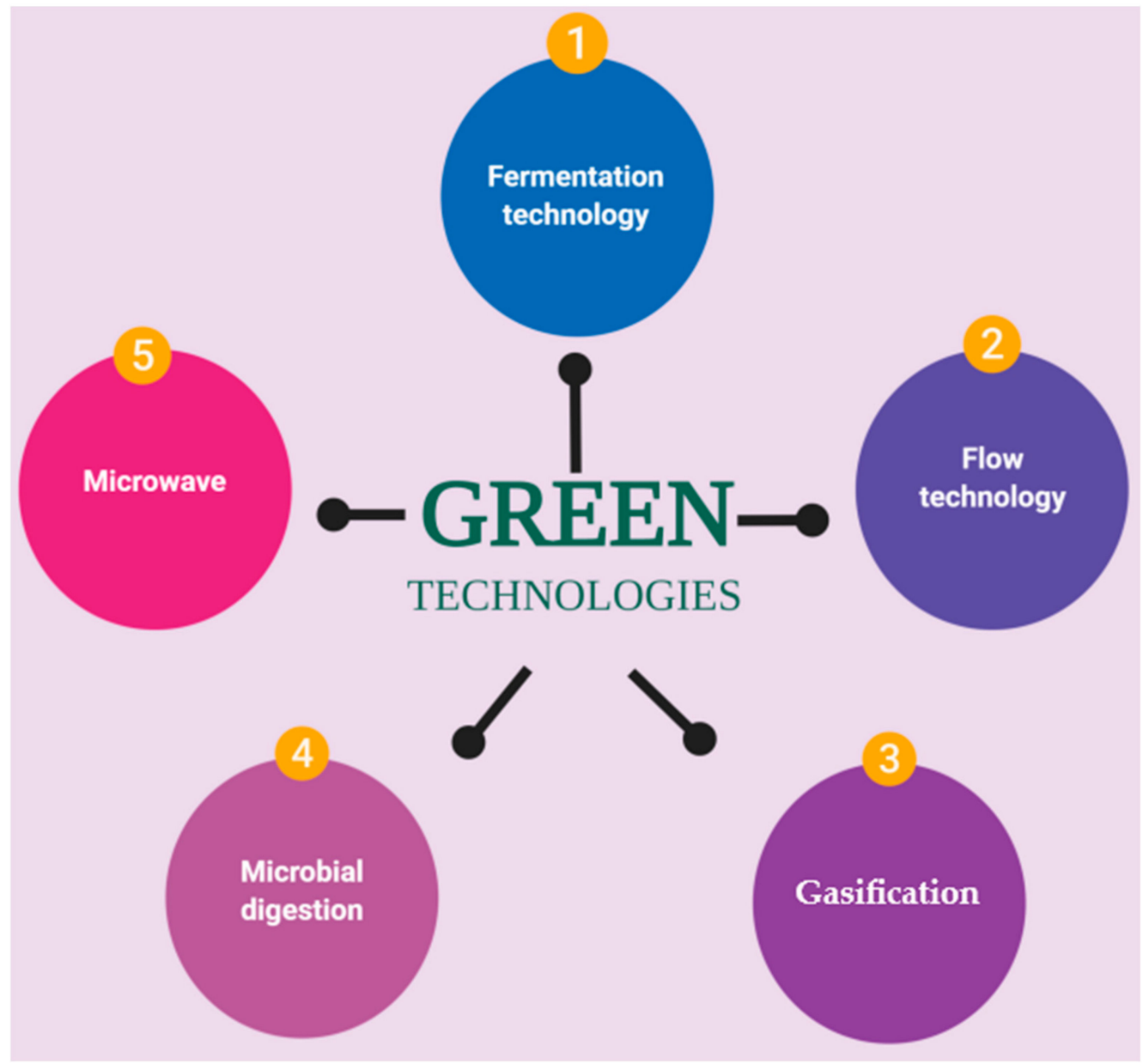

Figure 5. Green technologies applied for biomass and waste valorisation.

\subsection{Fermentation Technology}

On a commercial scale, fermentation is used in different countries to make ethanol. The synthesis of ethanol is performed using sugar crops (i.e., sugar beet) and starch crops (i.e., wheat). Starch combines with enzymes to convert sugars, sugars are transformed with yeast into ethanol $[65,66]$. Distillation of the ethanol is an energy-intensive phase and produces approximately $450 \mathrm{~mL}$ of ethanol per ton of dry maize. The strong residues used as a bovine feed form the fermentation method. For boilers or gasification, it can be used as a bagasse fuel. The more complex biomass is converting lingo-cellulosic biomass because long-chain polysaccharide molecules are present and require acid before the sugars are fermented to ethanol [14,67].

\subsection{Flow Technology}

When considering fresh procedures, the elevated amount of biomass's physical and chemical complexity is a major problem. One prospective key to overcoming the difficulty of biomass includes converting it into simpler fractions that are easier to handle in downstream procedures. In a single petroleum industry facility, bio-refinery is the source of chemicals, energy, and fuel production $[20,68,69]$. These significant biomass derivatives (so-called platform molecules or construction blocks) are comparatively easy compounds with various functionalities in their structures that are appropriate for a range of useful chemical compound transformations [70]. Continuous flow processing enables the response conditions to be better controlled. This is beneficial when dealing with extremely reactive feedstock such as biomass-derived feedstock. Flow processing also promotes scaling up, considering that many biomass procedures are still on the laboratory scale, 
which is a significant point. Therefore, the development of flow technologies in the near future will contribute to the marketing of biomass technologies [71,72]. Since the chemical structure of biomass feedstock is usually very distinct from that of the final products, various processing steps are typically needed in such transformations, negatively influencing the process economy. Using stream processing techniques enables chemical processes to be intensified, thereby contributing considerably to technology simplification [73].

\subsection{Gasification}

The gasification process is the partial oxidation of organic/natural products producing syngas at a constant temperature (i.e., $500-1800^{\circ} \mathrm{C}$ ). The gasification method appears as a char that responds to hydrogen and carbon monoxide with water vapour and $\mathrm{CO}_{2}$. In equilibrium reaction, the concentration of steam, $\mathrm{CO}_{2}$, hydrogen, and carbon monoxide become stable very fast at the given temperature in a gasifier [74,75], to produce heat or electricity, which is used as fuel through syngas. The gasification agents, which are the combination of carbon dioxide, oxygen, and steam, are used in a gasifier. The gasification process can be used as a cleaner and is a more logical technology than combustion [76]. Before its commercial organisation, biomass gasification must control some barriers. The main application of gasification is to remove tars, problems related to the production and pre-treatment of biomass feedstock, and the effect of biomass properties must be clearly understood [77]. Supercritical gasification of water in wet biomass is an advanced technology nowadays and seeks the attention of all big countries like the USA, Germany, Netherlands, and Japan [78]. Super Critical Water Gasification (SCWG) has the advantage that this technique does not require any dry method for the wet biomass before subjecting to gasification [79].

\subsection{Microbial Digestion}

Microbial digestion of organic matter through metabolic pathways leads to $\mathrm{CO}_{2}$ and methane formation [80,81]. Biogas is called a combination of coal dioxide and methane [82-84]. Anaerobic digestion gives renewable energy production possibilities and a higher quality of agro-residue-waste treatment. Recently, this technology became an appealing technique for biodegrading strong municipal waste organic fractions in Europe [85]. The method takes place in well-designed ships called the anaerobic bioreactor/anaerobic digester. A biogas plant includes the entire feedstock, digester, biogas holder, and digestive tank system.

\subsection{Microwave Technology}

Biomass feedstock is traditionally heated with pressure (i.e., $\sim 60-100$ bar). The heating activity is carried out between 180 and $200{ }^{\circ} \mathrm{C}$ in the closed vessel where oxygen $\left(\mathrm{O}_{2}\right)$

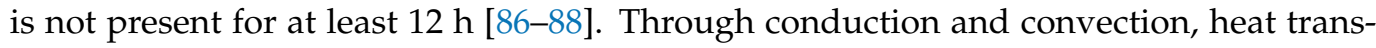
fer is accomplished through temperature gradients. Potential disadvantages of standard heating techniques include extended periods of residence and surface heating [89]. The microwave hydrothermal carbonization method was suggested to solve these disadvantages. Over the years, microwave technology has been used to substitute standard heating with carbohydrate [90,91] digestion, sterilisation [92], synthesis [93], and recently the dry pyrolysis method of the biomass feedstock to produce char and gas [56,94,95]. Besides the benefit of shorter periods of residence, microwave heating provides fast, selective, and volumetric heating, promoting fresh response paths and appropriate conditions for new products $[96,97]$.In conclusion, the operational considerations are met by the accurate and well-regulated nature of microwave technology and its prospective portable processing capability (owing to the comparatively small size of a reactor) [98]. The suitability of microwave heating to process human bio-wastes arises from their comparatively elevated water molecule, which is easily coupled with electromagnetic fields that cause "microwave dielectric heating" [99-101]. 


\section{Applied Potentialities-A Drive towards Sustainability}

Waste and biomass can be beneficial if proper techniques and conditions are applied to them, they can produce a huge variety of products. The world is moving towards the era where green energy is much preferred to fossil fuels. Two major factors that favour the use of green energy are using renewable resources, especially waste, and less pollution. Biomass and waste both possess other applications in different synthetic industries where they are processed as raw materials and supplements to improve the quality of various chemicals. Additional products and how they are synthesised from waste and/or biomass will be discussed in the following section.

\subsection{Biofuels and Energy Production}

Global energy demands have continued to increase since the beginning of the nineteenth century. To overcome these demands, fossil fuels were consumed at a higher rate. This higher rate of consumption imposed a threat of depletion of non-renewable resources of fossil fuels. Moreover, higher fossil fuel consumption increases carbon dioxide concentration hence the air pollution increases [102]. That is why alternative sources of energy are required. This has driven us into a new search to find renewable energy sources with a less negative impact on the environment. Biomass and waste, specifically organic waste, can be used as renewable energy production sources. The term "biofuel" involves bio-butanol, biodiesel, bioethanol, bioether, biogas, biohydrogen, and syngas [103].

Bioethanol: In the beginning of this field, sugar and starch crops were used to synthesise bioethanol. Using yeast species, e.g., Saccharomyces cerevisiae or Zymomonas mobilis six-carbon sugar-based biomass is fermented to produce bioethanol [67,104-106]. Sources used to provide this six-carbon sugar-based biomass are traditional feed stocks that are high in sugar like sugarcane, sugar beet, etc. [107-109]. To replace these traditional feedstocks, lignocellulosic biomass plays an important role. Lignocellulosic biomasses can be attained from these sources: wood chips, agricultural, forest residue, municipal and industrial solid wastes [110,111]. However, using lignocellulosic biomass requires pre-treatment action before its use to enhance the efficiency and yield [112]. The pre-treatment process increases the chances of availability of cellulose and hemicellulose for saccharification. To convert lignocellulosic biomass to ethanol, a biochemical route is taken in which biomass contents such as cellulose and hemicellulose are hydrolysed to release monomeric sugar, and thereby, these monomeric sugars are fermented to produce ethanol [113]. The process in which cellulose contents and hemicellulose contents are hydrolysed is termed saccharification. This saccharification activity is achieved in two ways; either using sulphuric acid in acid hydrolysis or using cellulose or xylanase enzymes in enzymatic hydrolysis [110,114]. Compared to acid hydrolysis, enzymatic hydrolysis gives a high yield and high selectivity with no by-products. However, fermentation can also be used in which S. cerevisiae acts as a fermentative microorganism. Bioethanol can be burnt directly or blended with petroleum, which reduces carbon dioxide emissions during petroleum consumption in automobiles. A study showed that using a commercial petroleum product known as E10 that contains petroleum blended with $10 \%$ ethanol can reduce the use of petroleum from $6 \%$ to $2 \%$ in $\mathrm{CO}_{2}$ emission and $3 \%$ in fossil fuels energy $[115,116]$.

Biodiesel: Transesterification is the process in which oil (extracted from oil nuts and seeds) is combined with alcohol (mostly methanol) to produce biodiesel. Transesterification can be of two types, catalytic or non-catalytic [117]. In catalytic transesterification, alkali catalysed transesterification is commonly used to produce biodiesel because it requires low temperature and pressure conditions with a 98\% yield of biodiesel [118-120]. However, enzyme catalysed transesterification is also used, but having costly enzymes and a slow reaction rate are the two main hurdles that prevent this process from being commercialised [121]. In non-catalytic transesterification, supercritical methanol (SCM) provides higher biodiesel concentration yield in a short time duration [122-124].

Biogas (biomethane, biohydrogen, and biohytane): Taking lignocellulosic biomass as a source to produce biofuels, anaerobic digestion is the cheapest, most stable, and well- 
established technique that recovers a higher amount of energy from the source [125-127]. Digestion of cellulose and hemicellulose (i.e., lignocellulosic biomass) underpins that anaerobic microbes can synthesise methane-rich biogas [128,129]. Lignin also reduces the substrate availability to the enzymes of anaerobic microbes, decreasing the productivity of methane [130]. The physicochemical properties, structure, and composition of lignocellulosic biomass can be altered using different pre-treatments, enhancing methane production [131-133]. The most preferred and commonly known technique is alkaline pre-treatment which solubilises lignin, cellulose, and hemicellulose. This technique is adapted to degrade the ester bonds present in-between carbohydrates and lignin and most prominently degrades the crystalline structure of the cellulose, which drastically affects the efficiency of anaerobic digestion $[125,126,134]$. The most commonly used alkali is sodium hydroxide $(\mathrm{NaOH})[130,135]$. This pre-treatment technique increases methane production from the lignocellulosic biomass (from $0 \%$ to $174.2 \%$ ) compared to untreated biomass $[136,137]$. Various process parameters affect the production of biomethane, such as type of inoculum [138], design of reactor [139], organic loading rate (OLR), $\mathrm{pH}$, temperature $\left({ }^{\circ} \mathrm{C}\right)$, carbon $(\mathrm{C})$ and nitrogen $(\mathrm{N})$ ratios, etc., [140]. Biohydrogen can act as a sustainable green fuel and replace fossil fuels as the main transportation fuel [141]. Three processes can be utilised to synthesise biohydrogen from biomass and waste; (i) biophotolysis, (ii) photofermentation, and (iii) anaerobic fermentation (AF) [142]. Production of biohydrogen can be enhanced by combining anaerobic fermentation with photofermentation, whereas the metabolites from the anaerobic fermentation can be utilised in photofermentation. Conjugation of these two techniques can be performed in a two-phase operation [143]. Biomethane and biohydrogen are mixed in the ratio of 1:4 to obtain biohythane [144]. Specific yields of biohydrogen and biomethane from a total volatile solid (TVS) feed are combined to make high-quality biohythane [145].

Biobutanol: Biobutanol can replace gasoline and is known as a drop-in-fuel. Crops having a high concentration of starch-like maize and wheat are good substrates for biobutanol production [146,147]. A study was performed in which acetone-butanol-ethanol (ABE) fermentation was conducted on the glucose-based culture of Clostridium beijerinckii. $A B E$ production took place until the fermentation terminated after $66 \mathrm{~h}$. About $0.46 \mathrm{~g} / \mathrm{L} / \mathrm{h}$ productivity was obtained based on the $41 \mathrm{~h}$ fermentation time [148,149].

\subsection{Organic Acids and Chemicals}

Besides biofuel and energy production, biomass and waste have a special position in synthesising different important synthetic chemicals and organic acids. In a study, scientists used kitchen waste as feedstock and converted the waste into organic acid using anaerobic digestion [150]. They found that with the increase in the fermentation media's $\mathrm{pH}$ and temperature, organic acid production increases. They examined four $\mathrm{pH}$ values (uncontrolled $\mathrm{pH}, \mathrm{pH} 5, \mathrm{pH} 6$ and $\mathrm{pH}$ 7) and five temperature values (uncontrolled at ambient, 30, 40, 50, and $60^{\circ} \mathrm{C}$ ) [151]. The fermentation period usually lasted for 10 days, and the yield of organic acid was detected using HPLC (high-pressure liquid chromatography) $[152,153]$. The composition of organic acids produced during fermentation contained a higher amount of lactic acid, about $65-85 \%$. However, $10-30 \%$ of acetic acid, $5-10 \%$ of propionic acid, and $5-20 \%$ of butyric acid yield were detected [154].

Acid-catalysed hydrolysis requires comparatively mild temperatures (i.e., $100-250{ }^{\circ} \mathrm{C}$ ) and performs a significant role in the bioenergy production that is commonly used to produce glucose, 5-hydroxymethylfurfural (5-HMF), and levulinic acid (LA) [155-157]. Removing a water molecule from all types of monomeric and polymeric carbohydrates makes them raw biomass used for 5-hydroxymethylfurfural (5-HMF) production [158]. Degradation of 5-hydroxymethylfurfural (5-HMF) in acidic conditions produces LA and formic acid (FA) with some chemicals as by-products. An intermediate 2, 5-dioxo-3hexenal is produced from 5-hydroxymethylfurfural (5-HMF) via a chain of hydration and rearrangement reactions. Formic acid is released from 2, 5-dioxo-3-hexenal, and after some rearrangement reactions, LA is produced $[159,160]$. 
Formic acid (FA) can be synthesised as a by-product in a process called biomass hydrolysis [161,162]. FA uses a hydrogen donor for hydrogenation of LA to yield fuel adjunct, like $\gamma$-valerolactone [163]. There are different methods to produce lactic acid. The first method is chemical synthesis, in which acidic hydrolysis of lactonitrile with strong acids results in D-lactic acid and L-lactic acid solutions $[19,164]$. The second method is based on fermentation using microbes which is more beneficial than chemical synthesis because microbial fermentation is more product specific and economical [165,166]. Microbes like lactic acid bacteria use pyruvate as substrate and convert pyruvate to lactic acid in combination with lactate dehydrogenase. These bacteria include Lactobacillus, Streptococcus, Tetragenococcus, and Weissella. Lactobacillus genus is the biggest and most prominent fungi, including Mucor, Monilia, and particularly Rhizopus to produce lactic acid [167].

Propionic acid (PA) $\left(\mathrm{C}_{3} \mathrm{H}_{6} \mathrm{O}_{2}\right)$ is a monocarboxylic acid. A bacteria known as propionibacteria is commonly utilised to produce $\mathrm{PA}$, providing anaerobic conditions to grow propionibacteria [168]. This bacteria is less tolerant to the acidic environment created due to the availability of produced propionic acid [169]. However, immobilisation of bacteria can increase their acid tolerating capacity. Additionally, they knocked out the gene for acetate kinase to reduce acetate production, which was beneficial in two ways. It increases propionic acid production in high concentrations and enhances the tolerance of bacteria to the acidic medium $[169,170]$.

Succinic acid (SA) $\left(\mathrm{C}_{4} \mathrm{H}_{6} \mathrm{O}_{4}\right)$ is a saturated dicarboxylic acid with a linear carbon chain and a white crystalline appearance under standard conditions. Succinic acid can be produced using different bacterial strains [171,172]. Phosphoenolpyruvate (PEP) directs carbon to the $\mathrm{C} 3$ pathway instead of the $\mathrm{C} 4$ pathway. PEP-carboxykinase produces oxaloacetate (OAA) by catalysing the reaction between PEP and carbon dioxide. There is a series of three reactions that convert oxaloacetate to succinic acid. Oxaloacetate is converted into malate, and malate is converted into fumarate, and finally, fumarate is converted into succinic acid. These three steps require electron donors like nicotinamide adenine dinucleotide (NAD) + hydrogen (H) (NADH), which supports the synthesis of succinic acid instead of formic acid and acetic acid $[167,173]$. Meynial-Salles et al. produced succinic acid ( $83 \mathrm{~g} / \mathrm{L})$ by cultivating an Anaerobiospirillum succiniciproducens strain in their developed integrated membrane-bioreactor-electrodialysis [174]. Glycerol and sorbitol are two carbon sources that are more reduced than glucose and xylose. Hence, both provide a concentrated yield of succinic acid $[175,176]$.

Malic acid (MA) $\left(\mathrm{C}_{4} \mathrm{H}_{6} \mathrm{O}_{5}\right)$ is known as a dicarboxylic acid that can be synthesised using various yeast strains, such as the fungus Aspergillus and Escherichia coli strains which are modified by genetic engineering for the fermentation process. Aspergillus flavus produced a high concentration of malic acid $(113 \mathrm{~g} / \mathrm{L})$ in batch cultures from glucose [177]. $A$. flavus produces aflatoxin which negatively affects their use in the production of foodgrade chemicals [167]. West reported a yield of $19.0 \mathrm{~g} / \mathrm{L}$ of MA using Aspergillus niger strain [178]. Moreover, Zhang et al. used a genetically engineered E. coli strain and produced $34 \mathrm{~g} / \mathrm{L}$ of malic acid by two-stage fermentation within $72 \mathrm{~h}$ [179]. The most promising results reported used a Zygosaccharomyces rouxii strain which used glucose in addition to $0.5 \%$ of glutamic acid and generated $74.90 \mathrm{~g} / \mathrm{L}$ of MA [180].

Fumaric acid $\left(\mathrm{C}_{4} \mathrm{H}_{4} \mathrm{O}_{4}\right)$ is also known as a dicarboxylic acid. Most studied fungi like Rhizopus arrhizus or Rhizopus oryzae can produce lactic acid or fumaric acid in an aerobic environment [167]. Ling and $\mathrm{Ng}$ reported the highest fumaric acid yield. They used $\mathrm{CaCO}_{3}$ as a neutralising agent and controlled the concentration of dissolved oxygen to $80-100 \%$ during fungal growth and $30-80 \%$ during the production of fumaric acid [181]. Cao et al. used immobilised fungal cells and reported the highest yield of fumaric acid, and via adsorption, they separated fumaric acid with high efficiency [181,182].

Butyric acid $\left(\mathrm{CH}_{3} \mathrm{CH}_{2} \mathrm{CH}_{2} \mathrm{COOH}\right)$ is recognised as a four-carbon-aliphatic organic acid. Microorganisms of different genera like Clostridium, Fusobacterium, Megasphera, and Eubacterium can be used to produce butyric acid from biomass and waste $[183,184]$. The strain of Clostridium tyrobutyricum produces butyric acid in anaerobic conditions and is a 
widely used strain all over the world. An elevated volumetric production was attained in the fermentation process of cane molasses by C. tyrobutyricum [185]. Immobilisation of cells can enhance the efficiency of butyric acid production $[184,186]$. In contrast, metabolic products find it challenging to produce butyric acid using the fermentation method because they inhibit fermentation [187]. The utilisation of mutants strain of C. tyrobutyricum ATCC 25755 instead of wild-type did not support the reduced acetic acid production [188]. Engineered strains could be potentially used to solve these problems when glucose is adapted as a carbon source. For example, genetically engineered immobilised $C$. tyrobutyricum produces a good yield of butyric acid [184].

\subsection{Enzymes and Lipids}

Biomass and waste, especially from food industries, are commonly used to produce industrial enzymes because of the low production cost of enzymes from food waste. A step known as enzymatic hydrolysis is involved in the lignocellulose pre-treatment [189] combined with the fermentation process in the presence of fungi that can grow and digest food waste is used to produce industrial enzymes, for example, Aspergillus sp, Melanocarpus sp, and Pleurotus sp. [190-192]. Different oxidative enzymes like amylase can be synthesised using food waste $[193,194]$. This waste's heterogenic nature can cause difficulties in downstream food waste processing, and in the end, isolation and purification of enzymes become highly expensive. To overcome these difficulties, purification in one step and enzyme immobilisation was performed $[195,196]$. To do one-step purification and immobilisation, three strategies are used: (i) immobilisation at one point, (ii) use of specially synthesised supports for specific binding, and (iii) use of directed mutagenesis to increase the affinity of target protein towards the supports [197]. Solid-state fermentation is a promising way to produce industrially important bacteria in a high amount with low manufacturing costs $[198,199]$. Because of their friendly nature with the solid-state fermentation process conditions, Basidiomycetes fungi are commonly used to synthesise most of the industrial enzymes [200,201].

Talking about non-enzymatic proteins, collagen is commonly found in organisms. It is also produced from food waste, and biomass like fish waste is broadly used as a biomass source to produce collagen [202,203]. In a study, $\mathrm{NaOH}$ was used to isolate acid-soluble collagen from all non-collagenous proteins present in cod bone [204]. Cheese whey waste water $(\mathrm{CWW})$ contains different proteins precipitated based upon their denaturation properties at high temperature and isoelectric $\mathrm{pH}$ [205]. Denaturation causes the unfolding and aggregation of proteins. The application of centrifugation and filtration methods after precipitation enhances the efficiency of separation and purification of protein fractions [61]. However, it is a challenge to make these isolated proteins thermally stable and functional [206,207].

Under other conditions, biomass and food waste are used to produce lipids. Lignocellulosic biomass and food wastes are commonly used organic carbon sources in the production of lipids. A drastic decrease in the cost of lipid production was observed $[208,209]$. To convert lignocellulosic biomass, microorganisms, specifically oleaginous microorganisms such as yeast algae and fungi are used [210]. Microorganisms produce lipid via fermentation, but the crystalline structure of cellulose and lignin contents requires pre-treatments such as acid, base, and enzymatic treatments, which will break down the crystalline structure of cellulose, making it available to microorganisms for fermentation [211,212]. After pre-treatments, biomass is fermented either in solid-state fermentation or submerged fermentation. The choice of fermentation state depends on the characteristics of available biomass, whether from rice or wheat, etc. [213]. Microorganisms use three different enzymes for the conversion of cellulose to lipids, which are Acetyl-CoA Carboxylase (ACC), Citrate Lyase (CL), and Malic Enzyme (ME) [214-216]. Different sources of biomass feedstock require various oleaginous microorganisms to carry out the fermentation process. For example, Trichosporon fermentas hydrolyses rice straw [217], Cryptococcus curvatus hydrolyses wheat straw [218], and Trichosporon cutaneum hydrolyses corn stover [219]. 


\subsection{Biological Macromolecules}

Biological macromolecules are cost-effectively produced by using biomass and waste. For example, bioplastics, polyhydroxyalkanoates (PHAs), lignin, cellulose, etc. To avoid the overconsumption of petroleum products in the plastic-making industry, scientists created a replacement known as bioplastic. Bioplastics are mainly composed of linear polyesters of hydroxy acids called polyhydroxyalkanoates (PHAs), a plastic-like material. The assembly of PHAs carried out by using biomass, and food waste reduces the cost of production and releases the stress of overconsumption of petroleum products [189]. A strain of Burkholderia sacchari (DSM-17165) can metabolise reducing sugars like glucose to produce poly-3-hydroxybutyrate (PHBs) (a simple type of PHAs). Moreover, coffee waste is an outstanding source of organic carbon for PHBs production. The solid portion left as residue contains cellulose and hemicellulose content. Starting with pre-treatment, these contents are converted into PHAs via enzymatic hydrolysis [220,221]. Reis and colleagues proposed another method to produce PHAs [222]. The first stage of the process is acidogenic fermentation (crucial for high yield of PHAs). The second stage is selecting and producing bacterial strain under dynamic feeding, and in the last stage, PHAs were accumulated in batch conditions. The first stage is very important because bacterial cultures tend to store glucose as glycogen, not as PHAs, acidogenic fermentation converts glucose into volatile fatty acids (VFA) that are easily convertible into PHAs [222].

The most abundant biopolymer present in nature is plant cellulose $\left(\mathrm{C}_{6} \mathrm{H}_{10} \mathrm{O}_{5}\right)_{\mathrm{n}}$. However, using this biopolymer for productive applications is very difficult because it cannot be attained in fully purified form because of the following components: lignin and hemicellulose. Different microorganisms like some algae (e.g., Rhodophyta, Phaeophyta) and bacteria were used to synthesise cellulose to avoid this difficulty. The synthesised cellulose possesses structural similarity but exhibits different properties than plant cellulose, like a higher degree of polymerisation, high purity, and more water holding capacity, making it suitable for industrial use [223-225]. Acetobacter xylinum carries cellulose synthase that adds uridine diphosphate glucose (UDP glucose) to the cellulose chain terminal. The rate of polymerisation is reduced by the rate of crystallisation of the cellulose complex. In the following step, bacterial cellulose egress bacterial cells in an elementary fibril forming a 3D network. The stated mechanism of bacterial cellulose is known as the "model microorganism" [226]. Some carbon sources such as glucose, glycerol, sucrose, and maltose are used to produce bacterial cellulose. Many studies revealed that the addition of various nutrient supplements resulted in a high yield of bacterial cellulose $[227,228]$. Gluconacetobacter xylinus was used in the fermentation process, and glucose was a source of carbon. The increase in bacterial cellulose production was observed when supplemented the lignosulfonate [229-231]. Researchers tried to achieve enhanced bacterial cellulose concentration. For this purpose, they used an agitated culture of Acetobacter xylinum and after trying different additives, they achieved the highest bacterial cellulose yield by the addition of carboxymethylcellulose [232].

\subsection{Food/Feed Products}

Different monomeric sugars like glucose, galactose, ribose, and fructose can be produced when food waste is treated with acids [233]. Low concentrations of $\mathrm{HCl}$ and $\mathrm{H}_{2} \mathrm{SO}_{4}$ are generally applied directly but can also be involved in conjugation with enzymes to avoid by-products that degrade sugars like furfurals. Additionally, different enzymes like $\alpha$-amylase and $\beta$-amylase can be used to degrade starch-like polymers to monomeric sugars [234-236]. The synergy of both treatments, such as enzyme hydrolysis can produce a higher yield of sugars. The enzyme (i.e., $\alpha$-amylase and glucoamylase) mediated hydrolytic treatment of kitchen waste and increase the yield of fermentable sugars. These sugars can later be used in the fermentation method to synthesise bioethanol [237-239]. Moreover, physical and chemical procedures may enhance the yield of monomeric sugars from polysaccharides [240,241]. Cellulase activity becomes less efficient because non-productive binding occurs in-between enzyme and lignin. To reduce this problem, surfactants are 
added that tend to inhibit the formation of enzyme-lignin complex [242]. It is believed that surfactants bind with the binding site of cellulase on the lignin molecule hence cellulase is available to bind with cellulose to produce sugars. Surfactant-mediated cellulose hydrolysis via cellulase enzyme enhances the sugar production from recycled newspaper or waste [243-245]. Various pre-treatment methods can be adopted to produce sugars depending upon the type of feed stock. If we talk about paper products like newspapers and office paper, different pre-treatment approaches such as steam explosion [246], bacterial pre-treatment [247], and ozonolysis [248] have been observed. However, weak acid pre-treatment of lignocellulosic biomass such as phosphoric acid showed many promising results $[249,250]$.

Edible mushrooms like Agaricus sp. and/or Grifola sp., etc., can ferment various agricultural wastes to harvest better-quality animal feed [251,252]. These fungi increase the degradation of lignocellulosic material using enzymatic activities and utilise the provided substrates to supplement animal feed's protein content [253,254]. In another study, S. cerevisiae produced single-cell protein from cucumber and orange peels in submerged fermentation. Protein content produced by cucumber peel is higher than from orange peel or other used substrates [255]. The advantage of food waste fermentation using fungi results in risk-free animal feed $[256,257]$. Lentinus edodes, Leurotus sp., Phanerochaete chrysosporium and Coriolus versicolor Phelbia sp. are highly studied white-rot fungi which are used to produce the improved animal feed [258-264]. Pleurotus sajor-caju was used to ferment rice straw, wheat straw, and soymeal, resulting in increased protein content $[265,266]$. Solidstate fermentation of wheat straw using fungal pellet inoculum of Trametes versicolor and Pleurotus ostreatus improves the nutrient availability and digestion of wheat straw [267]. Ref. [262] showed that inoculum-type is significant in lignin degradation under solid-state fermentation to achieve a high level of improved animal feed. Albeit, biomass, and waste are important to use in food production, but the type of inoculum and other optimised parameters are required for enhanced and improved quality production.

\subsection{Bioelectricity via Microbial Fuel Cell (MFC) Technology}

Bioelectricity is another useful product that can be synthesised from biomass and waste material. Lignocellulosic biomasses [268] and waste waters are a few biomass and waste residues that have been used in the past decade to produce bioelectricity via microbial fuel cell (MFC) technology [251]. Microbial fuel cell technology can convert the chemical energy of biomass and waste to bioelectricity $[269,270]$. Electrochemically active bacteria such as Shewanella putrefaciens, Geobacter sulfurreducens, etc., [271] can metabolically convert biomass and waste to bioelectricity [272]. The potential gradient of electrons (e-) and protons $\left(\mathrm{H}^{+}\right)$across the membrane developed by redox reactions in metabolic pathways of these bacteria generates electricity [273].

Just like an electrochemical cell, MFC systems also have anodes and cathodes separated by a membrane. The anodes catalyse the production of electrons and protons that electrochemically oxidise organic substrate. The terminal electron acceptor (TEA) present in the cathode, tends to force the electrons present in the anode to flow and harness energy externally. Protons $(\mathrm{H}+)$ form the anode move towards the cathode by passing the membrane [274]. It is a cathode chamber where the reduction of electrons $\left(\mathrm{e}^{-}\right)$and protons $\left(\mathrm{H}^{+}\right)$generate valuable products $[275,276]$. Microorganisms in MFCs catalyse the oxidation of biomass and food waste (anode) (Logan et al., 2006; Rabaey et al., 2007). Ref. [273] used integrated solid-state fermentation with MFCs to produce bioelectricity from merged canteen-based solid food waste. Microorganisms present in MFCs can utilise volatile fatty acids to generate bioelectricity [277-283]. Hydrolysis and acidogenic digestion of food waste leachate generate volatile product such as fatty acids [284], which are used in MFCs for bioelectricity $[285,286]$.

MFCs proved to be the most promising way to deal with biomass and waste material by converting them into bioelectricity. However, MFC technology also faced some hurdles like relatively low bioelectricity output because of high internal resistance $\left(R_{\text {int }}\right)$ [283]. To 
surpass this hurdle, scientists discovered that MFC power output could be improved if the anolyte and catholyte used in MFCs possess increased conductivity or ionic strength $[188,287]$. However, the proposed solution did not last permanently because varied salt tolerance of Anodophilic bacteria hinders increased ionic strength [288,289]. Ref. [290] added varying concentrations of $\mathrm{NaCl}$ to increase the ionic strength of the MFC chamber, which improves the output performance. In disagreement with the previously reported study, the highest columbic efficiency (CE) can be obtained at a lower $\mathrm{NaCl}$ concentration [289]. Anolyte $\mathrm{pH}$ also affects the power output of MFCs, affecting the MFC $\left(R_{\text {int }}\right)$ [291-294]. Ref. [283] described that the highest output of power $\left(P_{\max }\right)$ and lowest resistance $\left(R_{\text {int }}\right)$ is achieved when $100 \mathrm{mM} \mathrm{NaCl}$ is added in MFCs. This addition also increases the removing efficiency of chemical oxygen demand (COD). Neutral and alkaline MFCs can be more efficient in COD removal and CE. Moreover, neutral and alkaline conditions significantly increase $P_{\max }$ and decrease $R_{\text {int }}$. Along with the salt concentration, biomass, and food wastes, the $\mathrm{pH}$ range of anolyte can also affect the high-power density generation and COD removal using food waste leachate as a source to generate bioelectricity in MFCs.

\subsection{Paper and Pulp}

Another industrial field where biomass and waste materials play significant roles is in producing paper and pulp, where it is recognised as a very low-cost production method. In the paper and pulp industry, biomass and waste from different sources are used in two ways. Firstly, biomass and waste material were burnt to produce the green energy required to produce paper and pulp. Secondly, these are used as supplements that improved the product quality and manufacturing of paper and pulp [295]. Paper and pulp industries are adopting biomass and waste as fuel to produce green energy that is more efficient and safer. They have lower production costs than energy generated from fossil fuels. Other than combusting purposes, paper and pulp industries use these organic masses and residues as supplements and raw materials for their production. For example, filamentous algae utilised as raw materials to make papers [296,297]. Some biomass is based on algae mixed in conventional paper pulp to improve the quality of the paper. A case study published in 2006 showed that the supplementation of algal biomass for tissue paper production decreases the production cost. Production costs were almost fifty percent lower compared to conventional pulp [298].

\subsection{Pharmaceutical}

In the pharmaceutical industry, biomass and waste provide bioactive compounds with different pharmaceutical applications due to their properties such as antitumor, antioxidant, antibacterial, etc. [299,300]. Different biomass and waste feedstock can produce different bioactive compounds, a few of them will be discussed in this section for example lignocellulosic wastes, fungal biomass, and waste of seafood processing industries. Cultivation of Lentinula edodes on lignocellulosic waste produces high-value products. These products exhibit antivirus, anti-inflammatory, antibacterial polysaccharides, antitumor, and immunomodulating properties [301-303]. A compound named lentinan is a polysaccharide produced by Lentinula edodes cultured on lignocellulosic waste possessing anticlotting properties $[252,304]$ and is used as adjuvant therapy in cancer patients [251,305].

Different compounds produced from fungi exhibit bioactive properties that make them useful in the pharmaceutical industry. For example, an exocellular homopolysaccharide named pullulan is produced by the fungus Aureobasidium pullulans, and in the pharmaceutical industry, it is used as bulking and binding agent in tablet manufacturing [303]. Lentinan can be used as an antitumor, and it affects different cells of immune systems, for example, macrophages, to modulate the activity of the immune system $[305,306]$. Chihara et al. [307] isolated and purified lentinan polysaccharides from edible mushrooms known as Lentinus edodes using three different techniques [307]. Recently [308] extracted lentinan from Lentinus edodes mycelia using a series of centrifugation techniques and purified it by anion-exchange column chromatography [309]. Oral lentinan was observed to be more ef- 
fective than crude shiitake (Lentinus edodes) extract in inhibiting the colon carcinoma growth in mice [310,311]. Lentinan also exhibits antitumor activity against different synergic and autochthonous tumours and reduced tumour size by $90 \%$ in most specimens [312,313]. In conclusion, the production of tumour necrosis factor (TNF-a) can be induced by lentinan in macrophages in vitro and the phagocytotic activity of mouse macrophages can be increased by the lentinan addition [314].

\subsection{Miscellaneous}

Fish muscle can be digested very easily with specific amino acid concentration and composition [315,316]. Researchers observed the possibility of producing biologically active peptides from fish muscles $[317,318]$. Peptides and fish protein hydrolysates produced by enzymatic catalysis exhibit anticoagulant and antiplatelet properties [319,320]. Collagen and gelatine polypeptides are promising agents that can be used as potent antioxidants and antihypertensive treatments [321-324]. Microfibrous collagen sheets are very efficient drug carriers to treat cancer [325]. Chitin, chitosan, and their derivatives exhibit antioxidant, antibacterial, antifungal, and antiviral activities [326-328]. They additionally show antibacterial activity by disrupting the membrane integrity of the bacterial cell [329]. Wound dressing material [330] is an excellent practical example of chitin and its derivative in the pharmaceutical and medicinal field. Some organic wastes and residues, such as rice husk, wheat barn, wheat straw, eggshell, and banana peel, were proven to help produce nanoparticles. This portion will mention how these organic wastes and residues are helpful in the production of nanoparticles.

Span 40 rice husk silica (RHS) immobilised Ni particles produced from rice husk silica (RHS). The silica of rice husk is used as a surface to anchor Pt and Ni nanoparticles and then modified by CTAB (cetyl trimethylammonium bromide). Non-ionic surfactant (Span 40) is added to RHS immobilised Ni particles which change these nanoparticles to synthesise acetaldehyde [331] efficiently. An example of nanoparticles produced from biomass is silver nanoparticles. These nanoparticles were produced when xylan extracted from the wheat barn is dissolved in sodium hydroxide and heated to $100{ }^{\circ} \mathrm{C}$ for half an hour with $1 \mathrm{~mL}$ of silver nitrate. The appearance of brown colour confirms the presence of silver nanoparticles in the solution [332]. Calcination of wheat straw then treated with $\mathrm{NaOH}$ and neutralised by HCL produces 100-200 nm silica nanoparticles [333]. In a separate study, wheat straw and $\mathrm{Fe}\left(\mathrm{NO}_{3}\right)_{3} \cdot 9 \mathrm{H}_{2} \mathrm{O}$ were used to prepare porous carbon-supported $\mathrm{Fe}_{2} \mathrm{O}_{3}$ ultrathin film. Wheat straw was firstly calcinated under an inert environment, then $\mathrm{Fe}(\mathrm{II})$ was added to it followed by annealing at $200{ }^{\circ} \mathrm{C}$ producing porous carbonsupported $\mathrm{Fe}_{2} \mathrm{O}_{3}$ ultrathin film [334]. Jayasankar and co-workers prepared $\mathrm{Dy}^{3+}$-doped calcium silicate $\left(\mathrm{Ca}_{2} \mathrm{SiO}_{4}\right)$. They calcinated waste egg shell and rice husk at $1250{ }^{\circ} \mathrm{C}$ via solid-state reaction technique [335]. Calcium oxide nanoparticles were produced by using hen eggshells. Decomposition of crushed eggshells at a temperature above $800{ }^{\circ} \mathrm{C}$ makes $\mathrm{CaO}$. This $\mathrm{CaO}$ was remixed in water, and then the calcination of $\mathrm{CaO}$ resulted in the formation of calcium oxide nanoparticles [336]. The banana peel was used to make $\mathrm{Mn}_{3} \mathrm{O}_{4}$ nanoparticles of a size ranging from 20 to $50 \mathrm{~nm}$ by Yan and co-workers. They reported that banana peel reduces $\mathrm{KMnO} 4$ to form $\mathrm{Mn3O} 4$ and prevents nanoparticles' agglomeration during their synthesis [337]. Another type of nanoparticle produced from banana peel was $20 \mathrm{~nm} \mathrm{SiO} 2 \mathrm{NPs}$. An alkaline solution of tetraethyl orthosilicate in ethanol was mixed with banana peel extract. After calcination of this mixture, nanoparticles were participated out [338].

Fruit waste contains a high concentration of carbohydrates and essential nutrients, which substantiates fungal growth to synthesise the single-cell proteins [339,340]. Using fruit waste for this purpose can help in dealing with waste disposal and, to some extent, in controlling pollution. Different microorganisms such as algae, bacteria, fungi, mould, and yeast can be inoculated to produce single-cell proteins. S. cerevisiae, a single-cell eukaryote (baker's yeast) is the best example. Ref. [341] used pre-treated grounded peel to produce the single-cell protein. In the study, $40 \mathrm{gm}$ of ground peels was treated with 
$10 \%(w / v) \mathrm{HCl}$, and then the mixture was heated on a water bath for one hour at $1000{ }^{\circ} \mathrm{C}$. Filtering this mixture via Whatman filter paper after cooling it gave filtrate autoclaved for $15 \mathrm{~min}$ at $121^{\circ} \mathrm{C}$ after diluting the filtrate with distilled water. S. cerevisiae was used as a fermentation microorganism. Submerged fermentations in Erlenmeyer flasks gave a total carbohydrate yield of $39.66 \%$ produced from orange peel, which was lower than the yield made from cucumber peels. Furthermore, the quantity of crude protein $(53.4 \%)$ generated from cucumber peels was higher when compared to orange peels (30.5\%). In this study, they also used different growth media for S. cerevisiae. Growth media with extra glucose as a carbon source produces more protein and carbohydrates than the media with no excess glucose [255].

Non-renewable and unstable fossil fuels cannot be used to fulfil the energy demand around the globe for a long time because they are non-renewable and cause global warming, hence mankind should search for alternatives to fossil fuels [342]. Waste material, especially lignocellulosic biomass, produced as waste in huge amounts (200 billion tons), can be used to produce biofuel $[130,131]$. Because cellulose and hemicellulose are present, pre-treatment is required to enhance the production of biofuel. This study reported $\mathrm{NaOH}$ pre-treatment in conjugation with extrusion tends to enhance biomethane production. A Twin-Screw Extruder (manufactured by JXM80, Jinwor Machinery Co., Ltd., Nanjing, China) was used to reduce lignocellulosic biomass size $\mathrm{NaOH}$ was used as an alkaline reagent. After this pre-treatment, biomethane yield via anaerobic digestion of rice straw was $54.0 \%$ higher. Using this combination of pre-treatment with extrusion also increases the energy recovery efficiency (ER) (i.e., 38.9\% to 59.9\%). This increase in biomethane production and enhanced efficiency of the energy recovery (ER) were credited to the change in the lignocellulosic biomass's physiochemical structure. These changes increase the digestion in anaerobic digestion by degrading the cellulose and hemicellulose crystalline structure, hence increasing the biomethane production from rice straw [343].

New technology was developed to transform ferulic acid into vanillin by combining strains of fungi $A$. niger and Pycnoporus cinnabarinus. A. niger produces vanillic acid from free ferulic rice bran oil via preliminary treatment. Then vanillin is synthesised from vanillic acid by $P$. cinnabarinus cells. The highest yield of vanillic acid produced by $A$. niger was $2.2 \mathrm{~g} / \mathrm{L}$. P. cinnabarinus convert vanillic acid to vanillin and have $2.8 \mathrm{~g}$ of vanillin. ${ }^{13} \mathrm{C}$ isotopic analysis was used to identify and confirm the vanillin extracted in crystal form [344]. To simultaneously deal with waste treatment and globally increasing demand for energy generation, MFCs [345] are highly prominent in this context. MFCs can utilise chemical energy in waste materials to produce electrical energy by using catalytic bioprocesses of exo-electrogenic microorganisms $[285,286]$. This study reported the use of dual-chamber MFCs to produce bioelectricity from the LPW (liquid fraction of pressed municipal solid waste). Researchers studied the outcomes of adding substrate and mesophilic anaerobic sludge (MAS). Results of the experimental study tell that even with low input of chemical oxygen demand (COD), the highest energy (8-9 J/g $\Delta C O D / d$ ) can be produced by using this substrate in an MFC system. A 1.2-1.9 $\mathrm{kg}$ COD $/ \mathrm{m}^{3} \mathrm{~d}$ COD removal rate with $94 \%$ maximum efficiency could be reached. These results lead to the conclusion that substrate (LPW) concentration in an anode chamber is the major factor that affects the efficiency of energy recovery, and low organic material loadings improve the performance of MFC [346].

\section{Conclusions, Bioeconomy Challenges, and Socio-Economic Impacts}

Bioeconomy is a diverse field that deals with different types of productive activities like agricultural residues to produce biomass. These contribute to the bioeconomy by producing sustainable biomass quantities either in terms of waste or by-product. Biomass is considered a renewable source, but it is limited because of its production requirements like land and additional resources (water, nutrients) [347]. These requirements of the bioeconomy affect the environment because the bioeconomy requires feedstocks from land and sea to produce valuable bioproducts instead of using fossil fuel-derived feed stocks [348]. To establish a stable bioeconomy, a significant challenge is the conversion of fossil-based 
industry into the biomass-based industry. The development of industrial biotechnology (biorefineries), bio-based processes, and starting new markets to distribute the bio-based products made from these new industrial technologies are some of the significant changes that conventional industrial should adopt to establish a bioeconomy [347]. The most important question that arises to begin a bioeconomy is the supply of biomass to support and sustain the bioeconomy. This continues, and biomass's huge demand leads to increasing natural resources (water, land, etc.). More land is required to fulfil the massive demand for biomass and convert forests and grasslands to arable lands. This transformation of forests and grassland to an arable field releases $\mathrm{CO}_{2}$ into the atmosphere $[349,350]$. Thus, biocapturing $\mathrm{CO}_{2}$ from the environment is another valuable strategy to recover value-added products [349].

The excessive use of land decreases soil fertility and soil productivity [351]. Efficient and increased production of crops by using fertilizers and pesticides can improve water and soil pollution. Irrigation of these crops puts additional pressure on water sources and could lead to water scarcity. Biological sources of the economy can negatively affect the environment and increase pressure on natural sources required for biomass production. Strategically, these requirements destabilise food security, and due to this, price levels and volatility of food will be increased that will negatively affect the poor people of society. These challenges can be surpassed by using degraded land, increasing productivity, and waste utilisation of biomass production. Furthermore, micro-algae can promisingly reduce the competition with food due to their higher productivity, and they have no competition with food crops for agricultural lands. For example, food waste can be a good and sustainable source of biomass. However, using food waste has its own advantages with some critical issues like collection and separation of food waste, low coordination between suppliers of food waste, storing food waste for later use, limitations in technology, and economically stable plants $[348,352,353]$. The consumption of food waste to produce biomass needs huge public awareness because converting to a more sustainable circular model need strong public agreement [354].

Firstly, biofuels made from biomass can improve the local economy by replacing two fossil fuels (gasoline and diesel) enormously used in transportation. Biodiesel is the replacement for fossil diesel and bioethanol for gasoline. Using biomass-based fuels to meet energy requirements can potentially decrease $\mathrm{CO}_{2}$ released in the environment and sustain more employees due to its widespread opportunities. Biomass-based fuels are economically friendly because their diversity allows us to choose the transportation fuel depending upon the cost and availability of biomass for its production. For example, hydrogen and methanol can be synthesised from biomass, but hydrogen's synthesis cost is less than methanol [355]. With these biofuels, our dependency on fossil fuel will be reduced and there will be less greenhouse gas and pollutants in the environment. The bioeconomy can assist waste management by utilising municipal solid waste, vegetable and market waste, agricultural residue, slaughterhouse wastes, and industrial wastes to produce biofuels, energy, and other high-value products. Additionally, the bioeconomy produces new employment opportunities in different fields like biofuels' production and processing. The bioeconomy has many negative side effects, but those side effects are not permanent and can be easily surpassed. However, the benefits of the bioeconomy towards the environment and welfare of humankind can be sustainable for a long time if we discover and acquire those benefits very wisely.

Author Contributions: Conceptualization, I.A. and H.M.N.I.; data curation, M.A.Z., H.A., S.A. and M.A.; writing—original draft preparation, M.A.Z., H.A., S.A., M.A. and Z.A.; writing-review and editing, I.A., F.S. and H.M.N.I.; supervision, I.A.; project administration, I.A. All authors have read and agreed to the published version of the manuscript.

Funding: Consejo Nacional de Ciencia y Tecnología (CONACYT) is thankfully acknowledged for partially supporting this work under the Sistema Nacional de Investigadores (SNI) program awarded to Hafiz M.N. Iqbal (CVU: 735340). 
Institutional Review Board Statement: Not applicable.

Informed Consent Statement: Not applicable.

Data Availability Statement: Not applicable.

Acknowledgments: All listed authors are highly grateful to their representative institutes and universities for providing the literature services. This review study did not receive any specific grant from funding agencies in the public, commercial, or not-for-profit sectors.

Conflicts of Interest: The authors declare no conflict of interest.

\section{References}

1. Junginger, H.; Jonker, J.; Faaij, A. Summary, Synthesis and Conclusions from IEA Bioenergy Task 40 Country Reports on International Bioenergy Trade; Copernicus Institute, Utrecht University: Utrecht, The Netherlands, 2011; pp. 1-25. Available online: https: / / dspace.library.uu.nl/handle/1874/212189 (accessed on 31 March 2021).

2. Demirbas, M.F. Emissions of polychlorinated dibenzo-p-dioxins and dibenzofurans from biomass combustion and solid waste incineration. Energy Sources Part A Recover. Util. Environ. Eff. 2007, 29, 1041-1047. [CrossRef]

3. Monien, B.H.; Herrmann, K.; Florian, S.; Glatt, H. Metabolic activation of furfuryl alcohol: Formation of 2-methylfuranyl DNA adducts in Salmonella typhimurium strains expressing human sulfotransferase 1A1 and in FVB/N mice. Carcinogenesis 2011, 32, 1533-1539. [CrossRef] [PubMed]

4. Hall, D.O.; Rosillo-Calle, F.; Williams, R.H.; Woods, J. Biomass for energy: Supply prospects. In Biomass Energy Supply Prospect; Earthscan: London, UK, 1993; pp. 593-651, ISBN 1853831557.

5. Brunner, P.H.; Rechberger, H. Practical Handbook of Material Flow Analysis; CRC Press: Boca Raton, FL, USA, 2016; ISBN 9780203507209.

6. Awasthi, M.K.; Zhao, J.; Soundari, P.G.; Kumar, S.; Chen, H.; Awasthi, S.K.; Duan, Y.; Liu, T.; Pandey, A.; Zhang, Z. Sustainable Management of Solid Waste. In Sustainable Resource Recovery and Zero Waste Approaches; Elsevier: Amsterdam, The Netherlands, 2019; pp. 79-99.

7. Korhonen, J.; Honkasalo, A.; Seppälä, J. Circular Economy: The Concept and its Limitations. Ecol. Econ. 2018, 143, 37-46. [CrossRef]

8. Agarwal, M.; Jareda, K.; Bajpai, M. A review on solid waste management for smart city. SSRG Int. J. Civil Eng. (SSRG-IJCE) 2016, 3, 109-112.

9. Berndes, G.; Hoogwijk, M.; Van Den Broek, R. The contribution of biomass in the future global energy supply: A review of 17 studies. Biomass Bioenergy 2003, 25, 1-28. [CrossRef]

10. Kopetz, H. Renewable resources: Build a biomass energy market. Nature 2013, 494, 29-31. [CrossRef] [PubMed]

11. Chum, H.L.; Overend, R.P. Biomass and renewable fuels. Fuel Process. Technol. 2001, 71, 187-195. [CrossRef]

12. Saldarriaga-Hernández, S.; Velasco-Ayala, C.; Flores, P.L.I.; de Jesús Rostro-Alanis, M.; Parra-Saldivar, R.; Iqbal, H.M.; CarrilloNieves, D. Biotransformation of lignocellulosic biomass into industrially relevant products with the aid of fungi-derived lignocellulolytic enzymes. Int. J. Biol. Macromol. 2020, 161, 1099-1116. [CrossRef]

13. Razik, A.H.A.; Khor, C.S.; Elkamel, A. A model-based approach for biomass-to-bioproducts supply Chain network planning optimization. Food Bioprod. Proc. 2019, 118, 293-305. [CrossRef]

14. Bilal, M.; Iqbal, H.M. Recent Advancements in the Life Cycle Analysis of Lignocellulosic Biomass. Curr. Sustain. Renew. Energy Rep. 2020, 7, 100-107. [CrossRef]

15. Demirbaş, A. Biomass resource facilities and biomass conversion processing for fuels and chemicals. Energy Convers. Manag. 2001, 42, 1357-1378. [CrossRef]

16. Parikka, M. Global biomass fuel resources. Biomass Bioenergy 2004, 27, 613-620. [CrossRef]

17. Arevalo-Gallegos, A.; Ahmad, Z.; Asgher, M.; Parra-Saldivar, R.; Iqbal, H.M. Lignocellulose: A sustainable material to produce value-added products with a zero waste approach-A review. Int. J. Biol. Macromol. 2017, 99, 308-318. [CrossRef] [PubMed]

18. Cherubini, F. The biorefinery concept: Using biomass instead of oil for producing energy and chemicals. Energy Convers. Manag. 2010, 51, 1412-1421. [CrossRef]

19. John, R.P.; Sukumaran, R.K.; Nampoothiri, K.M.; Pandey, A. Statistical optimization of simultaneous saccharification and 1(+)-lactic acid fermentation from cassava bagasse using mixed culture of lactobacilli by response surface methodology. Biochem. Eng. J. 2007, 36, 262-267. [CrossRef]

20. Naik, S.N.; Goud, V.V.; Rout, P.K.; Dalai, A.K. Production of first and second generation biofuels: A comprehensive review. Renew. Sustain. Energy Rev. 2010, 14, 578-597. [CrossRef]

21. Kumar, A.; Kumar, N.; Baredar, P.; Shukla, A. A review on biomass energy resources, potential, conversion and policy in India. Renew. Sustain. Energy Rev. 2015, 45, 530-539. [CrossRef]

22. Balat, M.; Balat, H. Recent trends in global production and utilization of bio-ethanol fuel. Appl. Energy 2009, 86, $2273-2282$. [CrossRef]

23. Deublein, D.; Steinhauser, A. Biogas from Waste and Renewable Resources: An Introduction, 2nd, Revised and Expanded Edition; Current Reviews for Academic Libraries; John Wiley \& Sons: New Jersey, NJ, USA, 2010; p. 578, ISBN 978-3-527-32798-0. 
24. Mata, T.M.; Martins, A.A.; Caetano, N.S. Microalgae for biodiesel production and other applications: A review. Renew. Sustain. Energy Rev. 2010, 14, 217-232. [CrossRef]

25. Zeng, X.; Ma, Y.; Ma, L. Utilization of straw in biomass energy in China. Renew. Sustain. Energy Rev. 2007, 11, 976-987. [CrossRef]

26. Mendu, V.; Harman-Ware, A.E.; Crocker, M.; Jae, J.; Stork, J.; Morton, S.; Placido, A.; Huber, G.; Debolt, S. Identification and thermochemical analysis of high-lignin feedstocks for biofuel and biochemical production. Biotechnol. Biofuels 2011, 4. [CrossRef]

27. Mendu, V.; Shearin, T.; Campbell, J.E.; Stork, J.; Jae, J.; Crocker, M.; Huber, G.; DeBolt, S. Global bioenergy potential from high-lignin agricultural residue. Proc. Natl. Acad. Sci. USA 2012, 109, 4014-4019. [CrossRef]

28. Welker, C.M.; Balasubramanian, V.K.; Petti, C.; Rai, K.M.; De Bolt, S.; Mendu, V. Engineering plant biomass lignin content and composition for biofuels and bioproducts. Energies 2015, 8, 7654-7676. [CrossRef]

29. Li, W.; Amos, K.; Li, M.; Pu, Y.; DeBolt, S.; Ragauskas, A.J.; Shi, J. Fractionation and characterization of lignin streams from unique high-lignin content endocarp feedstocks. Biotechnol. Biofuels 2018, 11. [CrossRef]

30. Harman-Ware, A.E.; Crocker, M.; Pace, R.B.; Placido, A.; Morton, S.; DeBolt, S. Characterization of Endocarp Biomass and Extracted Lignin Using Pyrolysis and Spectroscopic Methods. Bioenergy Res. 2015, 8, 350-368. [CrossRef]

31. Dardick, C.D.; Callahan, A.M.; Chiozzotto, R.; Schaffer, R.J.; Piagnani, M.C.; Scorza, R. Stone formation in peach fruit exhibits spatial coordination of the lignin and flavonoid pathways and similarity to Arabidopsis dehiscence. BMC Biol. 2010, 8. [CrossRef] [PubMed]

32. Johnson, E.A.; Echavarri-Erasun, C. Chapter 3-Yeast biotechnology. In The Yeasts; Elsevier: San Diego, CA, USA, 2011; pp. 21-44. [CrossRef]

33. Siqueira, P.F.; Karp, S.G.; Carvalho, J.C.; Sturm, W.; Rodríguez-León, J.A.; Tholozan, J.L.; Singhania, R.R.; Pandey, A.; Soccol, C.R. Production of bio-ethanol from soybean molasses by Saccharomyces cerevisiae at laboratory, pilot and industrial scales. Bioresour. Technol. 2008, 99, 8156-8163. [CrossRef]

34. John, R.P.; Nampoothiri, K.M.; Pandey, A. Fermentative production of lactic acid from biomass: An overview on process developments and future perspectives. Appl. Microbiol. Biotechnol. 2007, 74, 524-534. [CrossRef] [PubMed]

35. Makkar, R.S.; Cameotra, S.S. Biosurfactant production by microorganisms on unconventional carbon sources. J. Surfactants Deterg. 1999, 2, 237-241. [CrossRef]

36. Nigam, P.S.; Singh, A. Production of liquid biofuels from renewable resources. Prog. Energy Combust. Sci. 2011, 37, 52-68. [CrossRef]

37. Panwar, N.L.; Kaushik, S.C.; Kothari, S. Role of renewable energy sources in environmental protection: A review. Renew. Sustain. Energy Rev. 2011, 15, 1513-1524. [CrossRef]

38. Bhutto, A.W.; Bazmi, A.A.; Zahedi, G. Greener energy: Issues and challenges for Pakistan-Biomass energy prospective. Renew. Sustain. Energy Rev. 2011, 15, 3207-3219. [CrossRef]

39. Turan, N.G.; Çoruh, S.; Akdemir, A.; Ergun, O.N. Municipal solid waste management strategies in Turkey. Waste Manag. 2009, 29, 465-469. [CrossRef]

40. Ionescu, G.; Rada, E.C.; Ragazzi, M.; Mărculescu, C.; Badea, A.; Apostol, T. Integrated municipal solid waste scenario model using advanced pretreatment and waste to energy processes. Energy Convers. Manag. 2013, 76, 1083-1092. [CrossRef]

41. Kupper, T.; Bürge, D.; Bachmann, H.J.; Güsewell, S.; Mayer, J. Heavy metals in source-separated compost and digestates. Waste Manag. 2014, 34, 867-874. [CrossRef] [PubMed]

42. Bridgwater, A.V.; Meier, D.; Radlein, D. An overview of fast pyrolysis of biomass. Org. Geochem. 1999, 30, 1479-1493. [CrossRef]

43. Sonesson, U.; Björklund, A.; Carlsson, M.; Dalemo, M. Environmental and economic analysis of management systems for biodegradable waste. Resour. Conserv. Recycl. 2000, 28, 29-53. [CrossRef]

44. Kiyasudeen, K.; Ibrahim, M.H.; Quaik, S.; Ismail, S.A. An introduction to anaerobic digestion of organic wastes. In Prospects of Organic Waste Management and the Significance of Earthworms; Springer: Cham, Switzerland, 2016; pp. 23-44. [CrossRef]

45. Vasco-Correa, J.; Khanal, S.; Manandhar, A.; Shah, A. Anaerobic digestion for bioenergy production: Global status, environmental and techno-economic implications, and government policies. Bioresour. Technol. 2018, 247, 1015-1026. [CrossRef]

46. Yokoyama, S. The Asian Biomass Handbook A Guide for Biomass Production and Utilization Support Project for Building Asian-Partnership for Environmentally Conscious Agriculture; Entrusted by Ministry of Agriculture, Forestry, and Fisheries; The Japan Institute of Energy: Tokyo, Japan, 2008.

47. Kircher, M. Sustainability of biofuels and renewable chemicals production from biomass. Curr. Opin. Chem. Biol. 2015, 29, 26-31. [CrossRef]

48. Brar, S.K.; Dhillon, G.S.; Soccol, C.R. Biotransformation of Waste Biomass into High Value Biochemicals; Springer Science \& Business Media: New York, NY, USA, 2013; ISBN 9781461480044.

49. Duku, M.H.; Gu, S.; Hagan, E. Ben A comprehensive review of biomass resources and biofuels potential in Ghana. Renew. Sustain. Energy Rev. 2011, 15, 404-415. [CrossRef]

50. Kögel-Knabner, I. The macromolecular organic composition of plant and microbial residues as inputs to soil organic matter. Soil Biol. Biochem. 2002, 34, 139-162. [CrossRef]

51. Zhang, N.; Li, S.; Xiong, L.; Hong, Y.; Chen, Y. Cellulose-hemicellulose interaction in wood secondary cell-wall. Model. Simul. Mater. Sci. Eng. 2015, 23. [CrossRef]

52. Flemming, H.C.; Wingender, J. The biofilm matrix. Nat. Rev. Microbiol. 2010, 8, 623-633. [CrossRef] 
53. Maki, M.; Leung, K.T.; Qin, W. The prospects of cellulase-producing bacteria for the bioconversion of lignocellulosic biomass The prospects of cellulase-producing bacteria for the bioconversion of lignocellulosic biomass Page 2 sur 8. Int. J. Biol. Sci. 2013, 5, 1-8. [CrossRef]

54. Ekman, A.; Börjesson, P. Environmental assessment of propionic acid produced in an agricultural biomass-based biorefinery system. J. Clean. Prod. 2011, 19, 1257-1265. [CrossRef]

55. Bilal, M.; Asgher, M.; Iqbal, H.M.; Hu, H.; Zhang, X. Biotransformation of lignocellulosic materials into value-added products-A review. Int. J. Biol. Macromol. 2017, 98, 447-458. [CrossRef] [PubMed]

56. Zhang, L.; Xu, C.; Champagne, P. Overview of recent advances in thermo-chemical conversion of biomass. Energy Convers. Manag. 2010, 51, 969-982. [CrossRef]

57. Van der Stelt, M.J.C.; Gerhauser, H.; Kiel, J.H.A.; Ptasinski, K.J. Biomass upgrading by torrefaction for the production of biofuels: A review. Biomass Bioenergy 2011, 35, 3748-3762. [CrossRef]

58. Demirbas, A. Combustion characteristics of different biomass fuels. Prog. Energy Combust. Sci. 2004, 30, 219-230. [CrossRef]

59. Jenkins, B.M.; Baxter, L.L.; Miles, T.R.; Miles, T.R. Combustion properties of biomass. Fuel Process. Technol. 1998, 54, 17-46. [CrossRef]

60. Lin, C.S.K.; Pfaltzgraff, L.A.; Herrero-Davila, L.; Mubofu, E.B.; Abderrahim, S.; Clark, J.H.; Koutinas, A.A.; Kopsahelis, N.; Stamatelatou, K.; Dickson, F.; et al. Food waste as a valuable resource for the production of chemicals, materials and fuels. Current situation and global perspective. Energy Environ. Sci. 2013, 6, 426-464. [CrossRef]

61. Lin, C.S.K.; Koutinas, A.A.; Stamatelatou, K.; Mubofu, E.B.; Matharu, A.S.; Kopsahelis, N.; Pfaltzgraff, L.A.; Clark, J.H.; Papanikolaou, S.; Kwan, T.H.; et al. Current and future trends in food waste valorization for the production of chemicals, materials and fuels: A global perspective. Biofuels Bioprod. Biorefin. 2014, 8, 686-715. [CrossRef]

62. Matharu, A.S.; de Melo, E.M.; Houghton, J.A. Food Supply Chain Waste: A Functional Periodic Table of Bio-Based Resources. In Waste Biorefinery; Elsevier: Amsterdam, The Netherlands, 2018; pp. 219-236.

63. Vlachokostas, C.; Achillas, C.; Diamantis, V.; Michailidou, A.V.; Baginetas, K.; Aidonis, D. Supporting decision making to achieve circularity via a biodegradable waste-to-bioenergy and compost facility. J. Environ. Manag. 2021, 285, 112215. [CrossRef] [PubMed]

64. Vlachokostas, C.; Michailidou, A.V.; Achillas, C. Multi-Criteria Decision Analysis towards promoting Waste-to-Energy Management Strategies: A critical review. Renew. Sust. Energ. Rev. 2021, 138, 110563. [CrossRef]

65. Gray, K.; Zhao, L.; Emptage, M. Bioethanol. Curr. Opin. Chem. Biol. 2006, 10, 141-146. [CrossRef]

66. You, C.; Chen, H.; Myung, S.; Sathitsuksanoh, N.; Ma, H.; Zhang, X.Z.; Li, J.; Zhang, Y.H.P. Enzymatic transformation of nonfood biomass to starch. Proc. Natl. Acad. Sci. USA 2013, 110, 7182-7187. [CrossRef]

67. Lin, Y.; Tanaka, S. Ethanol fermentation from biomass resources: Current state and prospects. Appl. Microbiol. Biotechnol. 2006, 69, 627-642. [CrossRef]

68. Bozell, J.J.; Petersen, G.R. Technology development for the production of biobased products from biorefinery carbohydrates-The US Department of Energy's "top 10" revisited. Green Chem. 2010, 12, 539-554. [CrossRef]

69. Tuck, C.O.; Pérez, E.; Horváth, I.T.; Sheldon, R.A.; Poliakoff, M. Valorization of biomass: Deriving more value from waste. Science 2012, 337, 695-699. [CrossRef]

70. Yue, D.; You, F.; Snyder, S.W. Biomass-to-bioenergy and biofuel supply chain optimization: Overview, key issues and challenges. Comput. Chem. Eng. 2014, 66, 36-56. [CrossRef]

71. Richard, T.L. Challenges in scaling up biofuels infrastructure. Science 2010, 329, 793-796. [CrossRef]

72. Agbor, V.B.; Cicek, N.; Sparling, R.; Berlin, A.; Levin, D.B. Biomass pretreatment: Fundamentals toward application. Biotechnol. Adv. 2011, 29, 675-685. [CrossRef]

73. Glasnov, T.N.; Kappe, C.O. The microwave-to-flow paradigm: Translating high-temperature batch microwave chemistry to scalable continuous-flow processes. Chem. A Eur. J. 2011, 17, 11956-11968. [CrossRef]

74. Ruiz, J.A.; Juárez, M.C.; Morales, M.P.; Muñoz, P.; Mendívil, M.A. Biomass gasification for electricity generation: Review of current technology barriers. Renew. Sustain. Energy Rev. 2013, 18, 174-183. [CrossRef]

75. Molino, A.; Chianese, S.; Musmarra, D. Biomass gasification technology: The state of the art overview. J. Energy Chem. 2016, 25, 10-25. [CrossRef]

76. Mondal, P.; Dang, G.S.; Garg, M.O. Syngas production through gasification and cleanup for downstream applications-Recent developments. Fuel Process. Technol. 2011, 92, 1395-1410. [CrossRef]

77. Lapuerta, M.; Hernández, J.J.; Pazo, A.; López, J. Gasification and co-gasification of biomass wastes: Effect of the biomass origin and the gasifier operating conditions. Fuel Process. Technol. 2008, 89, 828-837. [CrossRef]

78. Tock, J.Y.; Lai, C.L.; Lee, K.T.; Tan, K.T.; Bhatia, S. Banana biomass as potential renewable energy resource: A Malaysian case study. Renew. Sustain. Energy Rev. 2010, 14, 798-805. [CrossRef]

79. Gasafi, E.; Reinecke, M.Y.; Kruse, A.; Schebek, L. Economic analysis of sewage sludge gasification in supercritical water for hydrogen production. Biomass Bioenergy 2008, 32, 1085-1096. [CrossRef]

80. Antoni, D.; Zverlov, V.V.; Schwarz, W.H. Biofuels from microbes. Appl. Microbiol. Biotechnol. 2007, 77, 23-35. [CrossRef] [PubMed]

81. Gumisiriza, R.; Mshandete, A.M.; Rubindamayugi, M.S.T.; Kansiime, F.; Kivaisi, A.K. Enhancement of anaerobic digestion of Nile perch fish processing wastewater. Afr. J. Biotechnol. 2009, 8, 328-333. 
82. Cirne, D.G.; Paloumet, X.; Björnsson, L.; Alves, M.M.; Mattiasson, B. Anaerobic digestion of lipid-rich waste-Effects of lipid concentration. Renew. Energy 2007, 32, 965-975. [CrossRef]

83. Das Neves, L.C.M.; Converti, A.; Penna, T.C.V. Biogas production: New trends for alternative energy sources in rural and urban zones. Chem. Eng. Technol. 2009, 32, 1147-1153. [CrossRef]

84. Gupta, P.; Gupta, A. Biogas production from coal via anaerobic fermentation. Fuel 2014, 118, 238-242. [CrossRef]

85. Scarlat, N.; Motola, V.; Dallemand, J.F.; Monforti-Ferrario, F.; Mofor, L. Evaluation of energy potential of Municipal Solid Waste from African urban areas. Renew. Sustain. Energy Rev. 2015, 50, 1269-1286. [CrossRef]

86. Titirici, M.M.; Thomas, A.; Antonietti, M. Back in the black: Hydrothermal carbonization of plant material as an efficient chemical process to treat the $\mathrm{CO}_{2}$ problem? New J. Chem. 2007, 31, 787-789. [CrossRef]

87. Huber, G.W.; Iborra, S.; Corma, A. Synthesis of transportation fuels from biomass: Chemistry, catalysts, and engineering. Chem. Rev. 2006, 106, 4044-4098. [CrossRef]

88. Silveira, M.H.L.; Morais, A.R.C.; Da Costa Lopes, A.M.; Olekszyszen, D.N.; Bogel-Łukasik, R.; Andreaus, J.; Pereira Ramos, L. Current Pretreatment Technologies for the Development of Cellulosic Ethanol and Biorefineries. ChemSusChem 2015, 8, 3366-3390. [CrossRef] [PubMed]

89. Meyer, S.; Glaser, B.; Quicker, P. Technical, economical, and climate-related aspects of biochar production technologies: A literature review. Environ. Sci. Technol. 2011, 45, 9473-9483. [CrossRef]

90. Richel, A.; Paquot, M. Conversion of Carbohydrates Under Microwave Heating. In Carbohydrates-Comprehensive Studies on Glycobiology and Glycotechnology; InTech: Rijeka, Croatia, 2012. [CrossRef]

91. Kappe, C.O. Controlled microwave heating in modern organic synthesis. Angew. Chem. Int. Ed. 2004, 43, 6250-6284. [CrossRef]

92. Guo, L.; Li, X.M.; Bo, X.; Yang, Q.; Zeng, G.M.; Liao, D.X.; Liu, J.J. Impacts of sterilization, microwave and ultrasonication pretreatment on hydrogen producing using waste sludge. Bioresour. Technol. 2008, 99, 3651-3658. [CrossRef]

93. Hu, Y.; Liu, C.; Zhang, Y.; Ren, N.; Tang, Y. Microwave-assisted hydrothermal synthesis of nanozeolites with controllable size. Microporous Mesoporous Mater. 2009, 119, 306-314. [CrossRef]

94. Menéndez, J.A.; Inguanzo, M.; Pis, J.J. Microwave-induced pyrolysis of sewage sludge. Water Res. 2002, 36, 3261-3264. [CrossRef]

95. Digman, B.; Joo, H.S.; Kim, D.S. Recent progress in gasification/ pyrolysis technologies for biomass conversion to energy. Environ. Prog. Sustain. Energy 2009, 28, 47-51. [CrossRef]

96. Yin, C. Microwave-assisted pyrolysis of biomass for liquid biofuels production. Bioresour. Technol. 2012, 120, 273-284. [CrossRef] [PubMed]

97. Luque, R.; Menéndez, J.A.; Arenillas, A.; Cot, J. Microwave-assisted pyrolysis of biomass feedstocks: The way forward? Energy Environ. Sci. 2012, 5, 5481-5488. [CrossRef]

98. Guiotoku, M.; Rambo, C.R.; Hansel, F.A.; Magalhães, W.L.E.; Hotza, D. Microwave-assisted hydrothermal carbonization of lignocellulosic materials. Mater. Lett. 2009, 63, 2707-2709. [CrossRef]

99. Amr Sohby, J.C. Microwave-assisted biorefinery. Chem. Eng. Trans. 2010, 19, 211-212. [CrossRef]

100. Nomanbhay, S.; Salman, B.; Hussain, R.; Ong, M.Y. Microwave pyrolysis of lignocellulosic biomass-A contribution to power Africa. Energy Sustain. Soc. 2017, 7, 1-24. [CrossRef]

101. Narzari, R.; Bordoloi, N.; Sarma, B.; Gogoi, L.; Gogoi, N.; Borkotoki, B.; Kataki, R. Fabrication of biochars obtained from valorization of biowaste and evaluation of its physicochemical properties. Bioresour. Technol. 2017, 242, 324-328. [CrossRef]

102. Omer, A.M. Renewable building energy systems and passive human comfort solutions. Renew. Sustain. Energy Rev. 2008, 12, 1562-1587. [CrossRef]

103. Yang, X.; Choi, H.S.; Park, C.; Kim, S.W. Current states and prospects of organic waste utilization for biorefineries. Renew. Sustain. Energy Rev. 2015, 49, 335-349. [CrossRef]

104. Balat, M.; Balat, H.; Öz, C. Progress in bioethanol processing. Prog. Energy Combust. Sci. 2008, 34, 551-573. [CrossRef]

105. Limayem, A.; Ricke, S.C. Lignocellulosic biomass for bioethanol production: Current perspectives, potential issues and future prospects. Prog. Energy Combust. Sci. 2012, 38, 449-467. [CrossRef]

106. Vohra, M.; Manwar, J.; Manmode, R.; Padgilwar, S.; Patil, S. Bioethanol production: Feedstock and current technologies. J. Environ. Chem. Eng. 2014, 2, 573-584. [CrossRef]

107. Ho, D.P.; Ngo, H.H.; Guo, W. A mini review on renewable sources for biofuel. Bioresour. Technol. 2014, 169, 742-749. [CrossRef]

108. Zabed, H.; Faruq, G.; Sahu, J.N.; Azirun, M.S.; Hashim, R.; Nasrulhaq Boyce, A. Bioethanol production from fermentable sugar juice. Sci. World J. 2014, 2014, 957102. [CrossRef]

109. Sindhu, R.; Gnansounou, E.; Binod, P.; Pandey, A. Bioconversion of sugarcane crop residue for value added products-An overview. Renew. Energy 2016, 98, 203-215. [CrossRef]

110. Lee, R.A.; Lavoie, J.-M. From first- to third-generation biofuels: Challenges of producing a commodity from a biomass of increasing complexity. Anim. Front. 2013, 3, 6-11. [CrossRef]

111. Zabed, H.; Sahu, J.N.; Suely, A.; Boyce, A.N.; Faruq, G. Bioethanol production from renewable sources: Current perspectives and technological progress. Renew. Sustain. Energy Rev. 2017, 71, 475-501. [CrossRef]

112. Ravindran, R.; Jaiswal, A.K. A comprehensive review on pre-treatment strategy for lignocellulosic food industry waste: Challenges and opportunities. Bioresour. Technol. 2016, 199, 92-102. [CrossRef] [PubMed]

113. Zabed, H.; Sahu, J.N.; Boyce, A.N.; Faruq, G. Fuel ethanol production from lignocellulosic biomass: An overview on feedstocks and technological approaches. Renew. Sustain. Energy Rev. 2016, 66, 751-774. [CrossRef] 
114. Zhao, X.; Li, S.; Wu, R.; Liu, D. Organosolv fractionating pre-treatment of lignocellulosic biomass for efficient enzymatic saccharification: Chemistry, kinetics, and substrate structures. Biofuels, Bioprod. Biorefin. 2017, 11, 567-590. [CrossRef]

115. Wang, M.; Wu, M.; Huo, H. Life-cycle energy and greenhouse gas emission impacts of different corn ethanol plant types. Environ. Res. Lett. 2007, 2, 024001. [CrossRef]

116. Wyman, C.E. Ethanol Production from Lignocellulosic Biomass (No. CONF-950336-); American Society of Mechanical Engineers: New York, NY, USA, 1995.

117. Hassan, M.H.; Kalam, M.A. An overview of biofuel as a renewable energy source: Development and challenges. Procedia Eng. 2013, 56, 39-53. [CrossRef]

118. Balat, M.; Balat, H. Progress in biodiesel processing. Appl. Energy 2010, 87, 1815-1835. [CrossRef]

119. Musa, I.A. The effects of alcohol to oil molar ratios and the type of alcohol on biodiesel production using transesterification process. Egypt. J. Pet. 2016, 25, 21-31. [CrossRef]

120. Mishra, V.K.; Goswami, R. A review of production, properties and advantages of biodiesel. Biofuels 2018, 9, 273-289. [CrossRef]

121. Christopher, L.P.; Kumar, H.; Zambare, V.P. Enzymatic biodiesel: Challenges and opportunities. Appl. Energy 2014, 119, 497-520. [CrossRef]

122. Demirbaş, A. Diesel fuel from vegetable oil via transesterification and soap pyrolysis. Energy Sources 2002, 24, 835-842. [CrossRef]

123. Srivastava, G.; Paul, A.K.; Goud, V.V. Optimization of non-catalytic transesterification of microalgae oil to biodiesel under supercritical methanol condition. Energy Convers. Manag. 2018, 156, 269-278. [CrossRef]

124. Tran, D.T.; Chang, J.S.; Lee, D.J. Recent insights into continuous-flow biodiesel production via catalytic and non-catalytic transesterification processes. Appl. Energy 2017, 185, 376-409. [CrossRef]

125. Chen, X.; Gu, Y.; Zhou, X.; Zhang, Y. Asparagus stem as a new lignocellulosic biomass feedstock for anaerobic digestion: Increasing hydrolysis rate, methane production and biodegradability by alkaline pretreatment. Bioresour. Technol. 2014, 164, 78-85 [CrossRef] [PubMed]

126. Zheng, M.; Li, X.; Li, L.; Yang, X.; He, Y. Enhancing anaerobic biogasification of corn stover through wet state $\mathrm{NaOH}$ pretreatment. Bioresour. Technol. 2009, 100, 5140-5145. [CrossRef] [PubMed]

127. Sawatdeenarunat, C.; Nguyen, D.; Surendra, K.C.; Shrestha, S.; Rajendran, K.; Oechsner, H.; Xie, L.; Khanal, S.K. Anaerobic biorefinery: Current status, challenges, and opportunities. Bioresour. Technol. 2016, 215, 304-313. [CrossRef] [PubMed]

128. Chen, X.; Zhang, Y.L.; Gu, Y.; Liu, Z.; Shen, Z.; Chu, H.; Zhou, X. Enhancing methane production from rice straw by extrusion pretreatment. Appl. Energy 2014, 122, 34-41. [CrossRef]

129. Wu, N.; Moreira, C.M.; Zhang, Y.; Doan, N.; Yang, S.; Phlips, E.J.; Svoronos, S.A.; Pullammanappallil, P.C. Techno-Economic Analysis of Biogas Production from Microalgae through Anaerobic Digestion. In Anaerobic Digestion; IntechOpen: London, UK, 2019. [CrossRef]

130. Monlau, F.; Sambusiti, C.; Barakat, A.; Guo, X.M.; Latrille, E.; Trably, E.; Steyer, J.P.; Carrere, H. Predictive models of biohydrogen and biomethane production based on the compositional and structural features of lignocellulosic materials. Environ. Sci. Technol. 2012, 46, 12217-12225. [CrossRef]

131. Hendriks, A.T.W.M.; Zeeman, G. Pretreatments to enhance the digestibility of lignocellulosic biomass. Bioresour. Technol. 2009, 100, 10-18. [CrossRef]

132. He, Y.; Pang, Y.; Liu, Y.; Li, X.; Wang, K. Physicochemical characterization of rice straw pretreated with sodium hydroxide in the solid state for enhancing biogas production. Energy Fuels 2008, 22, 2775-2781. [CrossRef]

133. Rajput, A.A.; Zeshan; Visvanathan, C. Effect of thermal pretreatment on chemical composition, physical structure and biogas production kinetics of wheat straw. J. Environ. Manag. 2018, 221, 45-52. [CrossRef]

134. Zhu, J.; Wan, C.; Li, Y. Enhanced solid-state anaerobic digestion of corn stover by alkaline pretreatment. Bioresour. Technol. 2010, 101, 7523-7528. [CrossRef]

135. Salehian, P.; Karimi, K.; Zilouei, H.; Jeihanipour, A. Improvement of biogas production from pine wood by alkali pretreatment. Fuel 2013, 106, 484-489. [CrossRef]

136. Monlau, F.; Aemig, Q.; Barakat, A.; Steyer, J.P.; Carrère, H. Application of optimized alkaline pretreatment for enhancing the anaerobic digestion of different sunflower stalks varieties. Environ. Technol. 2013, 34, 2155-2162. [CrossRef] [PubMed]

137. Yao, Y.; He, M.; Ren, Y.; Ma, L.; Luo, Y.; Sheng, H.; Xiang, Y.; Zhang, H.; Li, Q.; An, L. Anaerobic digestion of poplar processing residues for methane production after alkaline treatment. Bioresour. Technol. 2013, 134, 347-352. [CrossRef] [PubMed]

138. Deepanraj, B.; Sivasubramanian, V.; Jayaraj, S. Multi-response optimization of process parameters in biogas production from food waste using Taguchi-Grey relational analysis. Energy Convers. Manag. 2017, 141, 429-438. [CrossRef]

139. Krishna, D.; Kalamdhad, A.S. Pre-treatment and anaerobic digestion of food waste for high rate methane production-A review. J. Environ. Chem. Eng. 2014, 2, 1821-1830.

140. Karthikeyan, O.P.; Visvanathan, C. Effect of $\mathrm{C} / \mathrm{N}$ ratio and ammonia-N accumulation in a pilot-scale thermophilic dry anaerobic digester. Bioresour. Technol. 2012, 113, 294-302. [CrossRef]

141. Dahiya, S.; Kumar, A.N.; Shanthi Sravan, J.; Chatterjee, S.; Sarkar, O.; Mohan, S.V. Food waste biorefinery: Sustainable strategy for circular bioeconomy. Bioresour. Technol. 2018, 248, 2-12. [CrossRef]

142. Venkata Mohan, S. Harnessing of biohydrogen from wastewater treatment using mixed fermentative consortia: Process evaluation towards optimization. Int. J. Hydrog. Energy 2009, 34, 7460-7474. [CrossRef] 
143. Chandra, R.; Nikhil, G.N.; Venkata Mohan, S. Single-stage operation of hybrid dark-photo fermentation to enhance biohydrogen production through regulation of system redox condition: Evaluation with real-field wastewater. Int. J. Mol. Sci. 2015, 16, 9540-9556. [CrossRef]

144. Pasupuleti, S.B.; Venkata Mohan, S. Single-stage fermentation process for high-value biohythane production with the treatment of distillery spent-wash. Bioresour. Technol. 2015, 189, 177-185. [CrossRef]

145. Cavinato, C.; Giuliano, A.; Bolzonella, D.; Pavan, P.; Cecchi, F. Bio-hythane production from food waste by dark fermentation coupled with anaerobic digestion process: A long-term pilot scale experience. Int. J. Hydrog. Energy 2012, 37, 11549-11555. [CrossRef]

146. Stoeberl, M.; Werkmeister, R.; Faulstich, M.; Russ, W. Biobutanol from food wastes-Fermentative production, use as biofuel an the influence on the emissions. Procedia Food Sci. 2011, 1, 1867-1874. [CrossRef]

147. Rodionova, M.V.; Poudyal, R.S.; Tiwari, I.; Voloshin, R.A.; Zharmukhamedov, S.K.; Nam, H.G.; Zayadan, B.K.; Bruce, B.D.; Hou, H.J.M.; Allakhverdiev, S.I. Biofuel production: Challenges and opportunities. Int. J. Hydrog. Energy 2017, 42, 8450-8461. [CrossRef]

148. Huang, H.; Singh, V.; Qureshi, N. Butanol production from food waste: A novel process for producing sustainable energy and reducing environmental pollution. Biotechnol. Biofuels 2015, 8. [CrossRef] [PubMed]

149. Qureshi, N.; Eller, F. Recovery of butanol from Clostridium beijerinckii P260 fermentation broth by supercritical CO2 extraction. J. Chem. Technol. Biotechnol. 2018, 93, 1206-1212. [CrossRef]

150. Jain, S.; Jain, S.; Wolf, I.T.; Lee, J.; Tong, Y.W. A comprehensive review on operating parameters and different pretreatment methodologies for anaerobic digestion of municipal solid waste. Renew. Sustain. Energy Rev. 2015, 52, 142-154. [CrossRef]

151. Zheng, X. A Traditional Fermentation Starter in China: Microbial Ecology and Functionality. Ph.D. Thesis, Wageningen University, Wageningen, The Netehrlands, 2015.

152. Bolado-Rodríguez, S.; Toquero, C.; Martín-Juárez, J.; Travaini, R.; García-Encina, P.A. Effect of thermal, acid, alkaline and alkaline-peroxide pretreatments on the biochemical methane potential and kinetics of the anaerobic digestion of wheat straw and sugarcane bagasse. Bioresour. Technol. 2016, 201, 182-190. [CrossRef]

153. Sträuber, H.; Bühligen, F.; Kleinsteuber, S.; Dittrich-Zechendorf, M. Carboxylic acid production from ensiled crops in anaerobic solid-state fermentation-Trace elements as $\mathrm{pH}$ controlling agents support microbial chain elongation with lactic acid. Eng. Life Sci. 2018, 18, 447-458. [CrossRef]

154. Loh, C.W.; Fakhru'l-Razi, A.; Hassan, M.A.; Karim, M.I.A. Production of organic acids from kitchen wastes. Artif. Cells. Blood Substit. Immobil. Biotechnol. 1999, 27, 455-459. [CrossRef]

155. Pileidis, F.D.; Titirici, M.M. Levulinic Acid Biorefineries: New Challenges for Efficient Utilization of Biomass. ChemSusChem 2016, 9, 562-582. [CrossRef]

156. Saha, B.; Abu-Omar, M.M. Advances in 5-hydroxymethylfurfural production from biomass in biphasic solvents. Green Chem. 2014, 16, 24-38. [CrossRef]

157. Alvira, P.; Tomás-Pejó, E.; Ballesteros, M.; Negro, M.J. Pretreatment technologies for an efficient bioethanol production process based on enzymatic hydrolysis: A review. Bioresour. Technol. 2010, 101, 4851-4861. [CrossRef] [PubMed]

158. Teong, S.P.; Yi, G.; Zhang, Y. Hydroxymethylfurfural production from bioresources: Past, present and future. Green Chem. 2014, 16, 2015-2026. [CrossRef]

159. Zhang, J.; Wu, S.; Li, B.; Zhang, H. Advances in the Catalytic Production of Valuable Levulinic Acid Derivatives. ChemCatChem 2012, 4, 1230-1237. [CrossRef]

160. Mulder, G.J. Untersuchungen über die Humussubstanzen. J. Prakt. Chemie 1840, 21, 203-240. [CrossRef]

161. Ahlkvist, J.; Wärnå, J.; Salmi, T.; Mikkola, J.P. Heterogeneously catalyzed conversion of nordic pulp to levulinic and formic acids. React. Kinet. Mech. Catal. 2016, 119, 415-427. [CrossRef]

162. Kang, S.; Yu, J. An intensified reaction technology for high levulinic acid concentration from lignocellulosic biomass. Biomass Bioenergy 2016, 95, 214-220. [CrossRef]

163. Heeres, H.; Handana, R.; Chunai, D.; Borromeus Rasrendra, C.; Girisuta, B.; Jan Heeres, H. Combined dehydration/(transfer)hydrogenation of C6-sugars (D-glucose and D-fructose) to $\gamma$-valerolactone using ruthenium catalysts. Green Chem. 2009, 11, 1247-1255. [CrossRef]

164. Djukić-Vuković, A.; Mladenović, D.; Ivanović, J.; Pejin, J.; Mojović, L. Towards sustainability of lactic acid and poly-lactic acid polymers production. Renew. Sustain. Energy Rev. 2019, 238-252. [CrossRef]

165. Thakur, K.; Tomar, S.K.; De, S. Lactic acid bacteria as a cell factory for riboflavin production. Microb. Biotechnol. $2016,9,441-451$. [CrossRef]

166. Rastogi, M.; Shrivastava, S. Recent advances in second generation bioethanol production: An insight to pretreatment, saccharification and fermentation processes. Renew. Sustain. Energy Rev. 2017, 80, 330-340. [CrossRef]

167. Koutinas, A.A.; Vlysidis, A.; Pleissner, D.; Kopsahelis, N.; Lopez Garcia, I.; Kookos, I.K.; Papanikolaou, S.; Kwan, T.H.; Lin, C.S.K. Valorization of industrial waste and by-product streams via fermentation for the production of chemicals and biopolymers. Chem. Soc. Rev. 2014, 43, 2587-2627. [CrossRef] [PubMed]

168. Wang, X.; Salvachúa, D.; Sànchez, V.N.I.; Michener, W.E.; Bratis, A.D.; Dorgan, J.R.; Beckham, G.T. Propionic acid production from corn stover hydrolysate by Propionibacterium acidipropionici. Biotechnol. Biofuels 2017, 10. [CrossRef] 
169. Guan, N.; Du, B.; Li, J.; Shin, H.D.; Chen, R.R.; Du, G.; Chen, J.; Liu, L. Comparative genomics and transcriptomics analysis-guided metabolic engineering of Propionibacterium acidipropionici for improved propionic acid production. Biotechnol. Bioeng. 2018, 115, 483-494. [CrossRef]

170. Zhang, A.; Yang, S.T. Engineering Propionibacterium acidipropionici for enhanced propionic acid tolerance and fermentation. Biotechnol. Bioeng. 2009, 104, 766-773. [CrossRef]

171. Beauprez, J.J.; De Mey, M.; Soetaert, W.K. Microbial succinic acid production: Natural versus metabolic engineered producers. Process Biochem. 2010, 45, 1103-1114. [CrossRef]

172. Ahn, J.H.; Jang, Y.S.; Lee, S.Y. Production of succinic acid by metabolically engineered microorganisms. Curr. Opin. Biotechnol. 2016, 42, 54-66. [CrossRef] [PubMed]

173. Pateraki, C.; Patsalou, M.; Vlysidis, A.; Kopsahelis, N.; Webb, C.; Koutinas, A.A.; Koutinas, M. Actinobacillus succinogenes: Advances on succinic acid production and prospects for development of integrated biorefineries. Biochem. Eng. J. 2016, 112, 285-303. [CrossRef]

174. Meynial-Salles, I.; Dorotyn, S.; Soucaille, P. A new process for the continuous production of succinic acid from glucose at high yield, titer, and productivity. Biotechnol. Bioeng. 2008, 99, 129-135. [CrossRef]

175. Yazdani, S.S.; Gonzalez, R. Anaerobic fermentation of glycerol: A path to economic viability for the biofuels industry. Curr. Opin. Biotechnol. 2007, 18, 213-219. [CrossRef]

176. Vlysidis, A.; Binns, M.; Webb, C.; Theodoropoulos, C. Glycerol utilisation for the production of chemicals: Conversion to succinic acid, a combined experimental and computational study. Biochem. Eng. J. 2011, 58-59, 1-11. [CrossRef]

177. Chi, Z.; Wang, Z.P.; Wang, G.Y.; Khan, I.; Chi, Z.M. Microbial biosynthesis and secretion of 1-malic acid and its applications. Crit. Rev. Biotechnol. 2016, 36, 99-107. [CrossRef] [PubMed]

178. West, T.P. Malic acid production from thin stillage by Aspergillus species. Biotechnol. Lett. 2011, 33, 2463-2467. [CrossRef]

179. Zhang, X.; Wang, X.; Shanmugam, K.T.; Ingram, L.O. L-malate production by metabolically engineered Escherichia coli. Appl. Environ. Microbiol. 2011, 77, 427-434. [CrossRef] [PubMed]

180. Taing, O.; Taing, K. Production of malic and succinic acids by sugar-tolerant yeast Zygosaccharomyces rouxii. Eur. Food Res. Technol. 2007, 224, 343-347. [CrossRef]

181. Maslova, O.; Stepanov, N.; Senko, O.; Efremenko, E. Production of various organic acids from different renewable sources by immobilized cells in the regimes of separate hydrolysis and fermentation (SHF) and simultaneous saccharification and fermentation (SFF). Bioresour. Technol. 2019, 272, 1-9. [CrossRef]

182. Cao, N.; Du, J.; Gong, C.S.; Tsao, G.T. Simultaneous Production and Recovery of Fumaric Acid from Immobilized Rhizopus oryzae with a Rotary Biofilm Contactor and an Adsorption Column. Appl. Environ. Microbiol. 1996, 62, 2926-2931. [CrossRef]

183. Zhang, C.; Yang, H.; Yang, F.; Ma, Y. Current progress on butyric acid production by fermentation. Curr. Microbiol. 2009, 59, 656-663. [CrossRef]

184. Jiang, L.; Wang, J.; Liang, S.; Cai, J.; Xu, Z.; Cen, P.; Yang, S.; Li, S. Enhanced butyric acid tolerance and bioproduction by Clostridium tyrobutyricum immobilized in a fibrous bed bioreactor. Biotechnol. Bioeng. 2011, 108, 31-40. [CrossRef]

185. Jiang, L.; Wang, J.; Liang, S.; Wang, X.; Cen, P.; Xu, Z. Butyric acid fermentation in a fibrous bed bioreactor with immobilized Clostridium tyrobutyricum from cane molasses. Bioresour. Technol. 2009, 100, 3403-3409. [CrossRef] [PubMed]

186. Huang, J.; Cai, J.; Wang, J.; Zhu, X.; Huang, L.; Yang, S.T.; Xu, Z. Efficient production of butyric acid from Jerusalem artichoke by immobilized Clostridium tyrobutyricum in a fibrous-bed bioreactor. Bioresour. Technol. 2011, 102, 3923-3926. [CrossRef]

187. Zhu, Y.; Wu, Z.; Yang, S.T. Butyric acid production from acid hydrolysate of corn fibre by Clostridium tyrobutyricum in a fibrous-bed bioreactor. Process Biochem. 2002, 38, 657-666. [CrossRef]

188. Liu, X.; Zhu, Y.; Yang, S.T. Butyric acid and hydrogen production by Clostridium tyrobutyricum ATCC 25755 and mutants. Enzyme Microb. Technol. 2006, 38, 521-528. [CrossRef]

189. Ravindran, R.; Jaiswal, A.K. Exploitation of Food Industry Waste for High-Value Products. Trends Biotechnol. 2016, 34, 58-69. [CrossRef]

190. Soni, R. Production, Purification and Industrial Applications of Cellulase from Aspergillus sp. AMA. Ph.D. Thesis, Guru Nanak Dev University Amritsar, Punjab, India, 2013.

191. Periyasamy, K.; Santhalembi, L.; Mortha, G.; Aurousseau, M.; Guillet, A.; Dallerac, D.; Sivanesan, S. Production, Partial Purification and Characterization of Enzyme Cocktail from Trichoderma citrinoviride AUKAR04 Through Solid-State Fermentation. Arab. J. Sci. Eng. 2017, 42, 53-63. [CrossRef]

192. Ahmed, I.; Zia, M.A.; Hussain, M.A.; Akram, Z.; Naveed, M.T.; Nowrouzi, A. Bioprocessing of citrus waste peel for induced pectinase production by Aspergillus niger; its purification and characterization. J. Radiat. Res. Appl. Sci. 2016, 9, 148-154. [CrossRef]

193. Stamatakis, G. Energy and geo-environmental applications for Olive Mill Wastes. A review. Hell. J. Geosci. 2010, 45, $269-282$.

194. Uçkun Kiran, E.; Trzcinski, A.P.; Ng, W.J.; Liu, Y. Enzyme Production from Food Wastes Using a Biorefinery Concept. Waste Biomass Valoriz. 2014, 5, 903-917. [CrossRef]

195. Garcia-Galan, C.; Berenguer-Murcia, Á.; Fernandez-Lafuente, R.; Rodrigues, R.C. Potential of different enzyme immobilization strategies to improve enzyme performance. Adv. Synth. Catal. 2011, 353, 2885-2904. [CrossRef]

196. Iqbal, H.M.N.; Kamal, S.; Ahmed, I.; Naveed, M.T. Enhanced bio-catalytic and tolerance properties of an indigenous cellulase through xerogel immobilization. Adv. Biosci. Biotechnol. 2012, 03, 308-313. [CrossRef] 
197. Hernandez, K.; Fernandez-Lafuente, R. Control of protein immobilization: Coupling immobilization and site-directed mutagenesis to improve biocatalyst or biosensor performance. Enzyme Microb. Technol. 2011, 48, 107-122. [CrossRef]

198. Ahmed, I.; Zia, M.A.; Iqbal, H.M.N. Detergent-compatible purified endoglucanase from the agro-industrial residue by Trichoderma harzianum under solid state fermentation. BioResources 2016, 11, 6393-6406. [CrossRef]

199. Dasari, P.R.; Ramteke, P.W.; Kesri, S.; Kongala, P.R. Comparative Study of Cellulase Production Using Submerged and Solid-State Fermentation. In New and Future Developments in Microbial Biotechnology and Bioengineering; Elsevier: Amsterdam, The Netherlands, 2019; pp. 37-52.

200. Viniegra-González, G.; Favela-Torres, E.; Aguilar, C.N.; de Jesus Rómero-Gomez, S.; Díaz-Godínez, G.; Augur, C. Advantages of fungal enzyme production in solid state over liquid fermentation systems. Biochem. Eng. J. 2003, 13, 157-167. [CrossRef]

201. Rodríguez-Couto, S. Fungal Laccase: A Versatile Enzyme for Biotechnological Applications. In Recent Advancement in White Biotechnology Through Fungi; Springer: Berlin/Heidelberg, Germany, 2019; pp. 429-457.

202. Voudouris, P.; Tamayo Tenorio, A.; Lesschen, J.P.; Kyriakopoulou, K.; Sanders, J.P.M.; van der Goot, A.J.; Bruins, M.E. Sustainable Protein Technology: An Evaluation on the STW Protein Programme and an Outlook for the Future; Wageningen Food \& Biobased Research (Wageningen Food \& Biobased Research Report 1786): Wageningen, The Netherlands, 2017; ISBN $9789463432368-58$.

203. Nagai, T.; Suzuki, N. Isolation of collagen from fish waste material—Skin, bone and fins. Food Chem. 2000, 68, 277-281. [CrossRef]

204. Wang, S.; Hou, H.; Hou, J.; Tao, Y.; Lu, Y.; Yang, X.; Li, B. Characterization of acid-soluble collagen from bone of pacific cod (gadus macrocephalus). J. Aquat. Food Prod. Technol. 2013, 22, 407-420. [CrossRef]

205. Yadav, J.S.S.; Yan, S.; Pilli, S.; Kumar, L.; Tyagi, R.D.; Surampalli, R.Y. Cheese whey: A potential resource to transform into bioprotein, functional/nutritional proteins and bioactive peptides. Biotechnol. Adv. 2015, 33, 756-774. [CrossRef]

206. Prabakaran, S.; Damodaran, S. Thermal Unfolding of $\beta$-Lactoglobulin: Characterization of Initial Unfolding Events Responsible for Heat-Induced Aggregation. J. Agric. Food Chem. 1997, 45, 4303-4308. [CrossRef]

207. Cuellas, A.; Jagus, R.; Wagner, J. Optimization of Proteins Recovery Process from Cheese Whey. J. Agric. Sci. Technol. B 2015, 5. [CrossRef]

208. Huang, C.; Chen, X.F.; Xiong, L.; de Chen, X.; Ma, L.L.; Chen, Y. Single cell oil production from low-cost substrates: The possibility and potential of its industrialization. Biotechnol. Adv. 2013, 31, 129-139. [CrossRef]

209. Merino, S.T.; Cherry, J.; Ave, D. Progress and Challenges in Enzyme Development for Biomass Utilization. Adv. Biochem. Eng. Biotechnol. 2007, 95-96.

210. Iniya, K. Single cell oil production from Mortierella sp for generation of biodiesel feedstock- a feasibility study. Afr. J. Microbiol. Res. 2011, 5. [CrossRef]

211. Berlin, A.; Maximenko, V.; Gilkes, N.; Saddler, J. Optimization of enzyme complexes for lignocellulose hydrolysis. Biotechnol. Bioeng. 2007, 97, 287-296. [CrossRef] [PubMed]

212. Kumar, P.; Barrett, D.M.; Delwiche, M.J.; Stroeve, P. Methods for pretreatment of lignocellulosic biomass for efficient hydrolysis and biofuel production. Ind. Eng. Chem. Res. 2009, 48, 3713-3729. [CrossRef]

213. Muniraj, I.K.; Uthandi, S.K.; Hu, Z.; Xiao, L.; Zhan, X. Microbial lipid production from renewable and waste materials for second-generation biodiesel feedstock. Environ. Technol. Rev. 2015, 4, 1-16. [CrossRef]

214. Ratledge, C. Fatty acid biosynthesis in microorganisms being used for Single Cell Oil production. Biochimie 2004, 86, 807-815. [CrossRef]

215. Jin, M.; Slininger, P.J.; Dien, B.S.; Waghmode, S.; Moser, B.R.; Orjuela, A.; da Costa Sousa, L.; Balan, V. Microbial lipid-based lignocellulosic biorefinery: Feasibility and challenges. Trends Biotechnol. 2015, 33, 43-54. [CrossRef] [PubMed]

216. Liao, J.C.; Mi, L.; Pontrelli, S.; Luo, S. Fuelling the future: Microbial engineering for the production of sustainable biofuels. Nat. Rev. Microbiol. 2016, 14, 288-304. [CrossRef]

217. Huang, C.; Zong, M.H.; Wu, H.; Liu, Q.P. Microbial oil production from rice straw hydrolysate by Trichosporon fermentans. Bioresour. Technol. 2009, 100, 4535-4538. [CrossRef]

218. Yu, X.; Zheng, Y.; Dorgan, K.M.; Chen, S. Oil production by oleaginous yeasts using the hydrolysate from pretreatment of wheat straw with dilute sulfuric acid. Bioresour. Technol. 2011, 102, 6134-6140. [CrossRef]

219. Huang, C.; Chen, X.F.; Xiong, L.; Yang, X.Y.; de Chen, X.; Ma, L.L.; Chen, Y. Microbial oil production from corncob acid hydrolysate by oleaginous yeast Trichosporon coremiiforme. Biomass Bioenergy 2013, 49, 273-278. [CrossRef]

220. Obruca, S.; Petrik, S.; Benesova, P.; Svoboda, Z.; Eremka, L.; Marova, I. Utilization of oil extracted from spent coffee grounds for sustainable production of polyhydroxyalkanoates. Appl. Microbiol. Biotechnol. 2014, 98, 5883-5890. [CrossRef] [PubMed]

221. Cruz, M.V.; Paiva, A.; Lisboa, P.; Freitas, F.; Alves, V.D.; Simões, P.; Barreiros, S.; Reis, M.A.M. Production of polyhydroxyalkanoates from spent coffee grounds oil obtained by supercritical fluid extraction technology. Bioresour. Technol. 2014, 157, 360-363. [CrossRef]

222. Reis, M.; Albuquerque, M.; Villano, M.; Majone, M. Mixed Culture Processes for Polyhydroxyalkanoate Production from AgroIndustrial Surplus/Wastes as Feedstocks. In Comprehensive Biotechnology, 2nd ed.; Elsevier: Amsterdam, The Netherlands, 2011; Volume 6, pp. 669-683, ISBN 9780080885049.

223. Khan, T.; Park, J.K.; Kwon, J.H. Functional biopolymers produced by biochemical technology considering applications in food engineering. Korean J. Chem. Eng. 2007, 24, 816-826. [CrossRef]

224. Shi, Z.; Zhang, Y.; Phillips, G.O.; Yang, G. Utilization of bacterial cellulose in food. Food Hydrocoll. 2014, 35, 539-545. [CrossRef] 
225. Sulaeva, I.; Henniges, U.; Rosenau, T.; Potthast, A. Bacterial cellulose as a material for wound treatment: Properties and modifications: A review. Biotechnol. Adv. 2015, 33, 1547-1571. [CrossRef]

226. Klemm, D.; Heublein, B.; Fink, H.P.; Bohn, A. Cellulose: Fascinating biopolymer and sustainable raw material. Angew. Chemie Int. Ed. 2005, 44, 3358-3393. [CrossRef]

227. Sharma, C.; Bhardwaj, N.K. Bacterial nanocellulose: Present status, biomedical applications and future perspectives. Mater. Sci. Eng. C 2019, 104, 109963. [CrossRef]

228. Albuquerque, P.B.S.; Malafaia, C.B. Perspectives on the production, structural characteristics and potential applications of bioplastics derived from polyhydroxyalkanoates. Int. J. Biol. Macromol. 2018, 107, 615-625. [CrossRef]

229. Kuo, C.H.; Chen, J.H.; Liou, B.K.; Lee, C.K. Utilization of acetate buffer to improve bacterial cellulose production by Gluconacetobacter xylinus. Food Hydrocoll. 2016, 53, 98-103. [CrossRef]

230. Huang, C.; Guo, H.J.; Xiong, L.; Wang, B.; Shi, S.L.; Chen, X.F.; Lin, X.Q.; Wang, C.; Luo, J.; Chen, X. De Using wastewater after lipid fermentation as substrate for bacterial cellulose production by Gluconacetobacter xylinus. Carbohydr. Polym. 2016, 136, 198-202. [CrossRef]

231. Jozala, A.F.; Pértile, R.A.N.; dos Santos, C.A.; de Carvalho Santos-Ebinuma, V.; Seckler, M.M.; Gama, F.M.; Pessoa, A. Bacterial cellulose production by Gluconacetobacter xylinus by employing alternative culture media. Appl. Microbiol. Biotechnol. 2015, 99, 1181-1190. [CrossRef] [PubMed]

232. Cheng, K.C.; Catchmark, J.M.; Demirci, A. Effect of different additives on bacterial cellulose production by Acetobacter xylinum and analysis of material property. Cellulose 2009, 16, 1033-1045. [CrossRef]

233. Hafid, H.S.; Rahman, N.A.; Md Shah, U.K.; Baharudin, A.S. Enhanced fermentable sugar production from kitchen waste using various pretreatments. J. Environ. Manag. 2015, 156, 290-298. [CrossRef] [PubMed]

234. Jiang, J.; Gong, C.; Wang, J.; Tian, S.; Zhang, Y. Effects of ultrasound pre-treatment on the amount of dissolved organic matter extracted from food waste. Bioresour. Technol. 2014, 155, 266-271. [CrossRef]

235. Mäki-Arvela, P.; Salmi, T.; Holmbom, B.; Willför, S.; Murzin, D.Y. Synthesis of sugars by hydrolysis of hemicelluloses-A review. Chem. Rev. 2011, 111, 5638-5666. [CrossRef]

236. Miao, M.; Jiang, B.; Jin, Z.; BeMiller, J.N. Microbial Starch-Converting Enzymes: Recent Insights and Perspectives. Compr. Rev. Food Sci. Food Saf. 2018, 17, 1238-1260. [CrossRef]

237. Yan, S.; Li, J.; Chen, X.; Wu, J.; Wang, P.; Ye, J.; Yao, J. Enzymatical hydrolysis of food waste and ethanol production from the hydrolysate. Renew. Energy 2011, 36, 1259-1265. [CrossRef]

238. Moon, H.C.; Song, I.S.; Kim, J.C.; Shirai, Y.; Lee, D.H.; Kim, J.K.; Chung, S.O.; Kim, D.H.; Oh, K.K.; Cho, Y.S. Enzymatic hydrolysis of food waste and ethanol fermentation. Int. J. Energy Res. 2009, 33, 164-172. [CrossRef]

239. Li, P.; Zeng, Y.; Xie, Y.; Li, X.; Kang, Y.; Wang, Y.; Xie, T.; Zhang, Y. Effect of pretreatment on the enzymatic hydrolysis of kitchen waste for xanthan production. Bioresour. Technol. 2017, 223, 84-90. [CrossRef]

240. Qin, L.; Liu, Z.H.; Li, B.Z.; Dale, B.E.; Yuan, Y.J. Mass balance and transformation of corn stover by pretreatment with different dilute organic acids. Bioresour. Technol. 2012, 112, 319-326. [CrossRef]

241. De Bhowmick, G.; Sarmah, A.K.; Sen, R. Lignocellulosic biorefinery as a model for sustainable development of biofuels and value added products. Bioresour. Technol. 2018, 247, 1144-1154. [CrossRef] [PubMed]

242. Saini, J.K.; Patel, A.K.; Adsul, M.; Singhania, R.R. Cellulase adsorption on lignin: A roadblock for economic hydrolysis of biomass. Renew. Energy 2016, 98, 29-42. [CrossRef]

243. Sung, B.K.; Hyun, J.K.; Chang, J.K. Enhancement of the enzymatic digestibility of waste newspaper using Tween. Appl. Biochem. Biotechnol. 2006, 130, 486-495.

244. Kim, H.J.; Kim, S.B.; Kim, C.J. The effects of nonionic surfactants on the pretreatment and enzymatic hydrolysis of recycled newspaper. Biotechnol. Bioprocess Eng. 2007, 12, 147-151. [CrossRef]

245. $\mathrm{Wu}, \mathrm{J} . ; \mathrm{Ju}$, L.K. Enhancing enzymatic saccharification of waste newsprint by surfactant addition. Biotechnol. Prog. 1998, 14, 649-652. [CrossRef]

246. Sangkharak, K. Optimization of enzymatic hydrolysis for ethanol production by simultaneous saccharification and fermentation of wastepaper. Waste Manag. Res. 2011, 29, 1134-1144. [CrossRef]

247. Kurakake, M.; Ide, N.; Komaki, T. Biological pretreatment with two bacterial strains for enzymatic hydrolysis of office paper. Curr. Microbiol. 2007, 54, 424-428. [CrossRef]

248. Kojima, Y.; Yoon, S.L. Improved enzymatic hydrolysis of waste paper by ozone pretreatment. J. Mater. Cycles Waste Manag. 2008, 10, 134-139. [CrossRef]

249. Kim, J.W.; Mazza, G. Optimization of phosphoric acid catalyzed fractionation and enzymatic digestibility of flax shives. Ind. Crops Prod. 2008, 28, 346-355. [CrossRef]

250. Loow, Y.L.; Wu, T.Y.; Jahim, J.M.; Mohammad, A.W.; Teoh, W.H. Typical conversion of lignocellulosic biomass into reducing sugars using dilute acid hydrolysis and alkaline pretreatment. Cellulose 2016, 23, 1491-1520. [CrossRef]

251. Liguori, R.; Amore, A.; Faraco, V. Waste valorization by biotechnological conversion into added value products. Appl. Microbiol. Biotechnol. 2013, 97, 6129-6147. [CrossRef] [PubMed]

252. Zervakis, G.I.; Koutrotsios, G. Solid-State Fermentation of Plant Residues and Agro-industrial Wastes for the Production of Medicinal Mushrooms. In Medicinal Plants and Fungi: Recent Advances in Research and Development; Springer: Singapore, 2017; pp. 365-396. 
253. Gupta, V.K.; Kubicek, C.P.; Berrin, J.G.; Wilson, D.W.; Couturier, M.; Berlin, A.; Filho, E.X.F.; Ezeji, T. Fungal Enzymes for Bio-Products from Sustainable and Waste Biomass. Trends Biochem. Sci. 2016, 41, 633-645. [CrossRef] [PubMed]

254. Oshoma, C.; Eguakun-Owie, S. Conversion of Food waste to Single Cell Protein using Aspergillus Niger. J. Appl. Sci. Environ. Manag. 2018, 22, 350. [CrossRef]

255. Mondal, A.K.; Sengupta, S.; Bhowal, J.; Bhattacharya, D.K. Utilization of Fruit Wastes in Producing Single Cell Protein. Int. J. Sci. Environ. Technol. 2012, 1, 430-438.

256. Howard, R.L.; Abotsi, E.; Van Rensburg, E.L.J.; Howard, S. Lignocellulose biotechnology: Issues of bioconversion and enzyme production. Afr. J. Biotechnol. 2003, 2, 702-733. [CrossRef]

257. Sadh, P.K.; Duhan, S.; Duhan, J.S. Agro-industrial wastes and their utilization using solid state fermentation: A review. Bioresour. Bioprocess. 2018, 5, 1-15. [CrossRef]

258. Yadav, J.S.; Tripathi, J.P. Optimization of cultivation and nutrition conditions and substrate pretreatment for solid-substrate fermentation of wheat straw by Coriolus versicolor. Folia Microbiol. 1991, 36, 294-301. [CrossRef]

259. Iqbal Zafar, S.; Sheeraa, Q.; Abdullah, N. Degradation of the lignocellulosic component on wheat straw-Coriolus versicolor solid state fermentation under nitrogen-starved conditions. Biol. Wastes 1989, 27, 67-70. [CrossRef]

260. Tripathi, J.P.; Yadav, J.S. Optimisation of solid substrate fermentation of wheat straw into animal feed by Pleurotus ostreatus: A pilot effort. Anim. Feed Sci. Technol. 1992, 37, 59-72. [CrossRef]

261. Moyson, E.; Verachtert, H. Growth of higher fungi on wheat straw and their impact on the digestibility of the substrate. Appl. Microbiol. Biotechnol. 1991, 36, 421-424. [CrossRef]

262. Basu, S.; Gaur, R.; Gomes, J.; Sreekrishnan, T.R.; Bisaria, V.S. Effect of seed culture on solid-state bioconversion of wheat straw by Phanerochaete chrysosporium for animal feed production. J. Biosci. Bioeng. 2002, 93, 25-30. [CrossRef]

263. Okano, K.; Ohkoshi, N.; Nishiyama, A.; Usagawa, T.; Kitagawa, M. Improving the nutritive value of madake bamboo, Phyllostachys bambusoides, for ruminants by culturing with the white-rot fungus Ceriporiopsis subvermispora. Anim. Feed Sci. Technol. 2009, 152, 278-285. [CrossRef]

264. Shabtay, A.; Hadar, Y.; Eitam, H.; Brosh, A.; Orlov, A.; Tadmor, Y.; Izhaki, I.; Kerem, Z. The potential of Pleurotus-treated olive mill solid waste as cattle feed. Bioresour. Technol. 2009, 100, 6457-6464. [CrossRef]

265. Bisaria, R.; Madan, M.; Vasudevan, P. Utilisation of agro-residues as animal feed through bioconversion. Bioresour. Technol. 1997, 59, 5-8. [CrossRef]

266. Mandyam, K.; Njiti, V.; Singleton, R.; Nanjundaswamy, A.K. Fermentation Optimization of Macro-Fungus Pleurotus Sajor-Caju on Soymeal. Ferment. Technol. 2017, 6. [CrossRef]

267. Shrivastava, B.; Thakur, S.; Khasa, Y.P.; Gupte, A.; Puniya, A.K.; Kuhad, R.C. White-rot fungal conversion of wheat straw to energy rich cattle feed. Biodegradation 2011, 22, 823-831. [CrossRef] [PubMed]

268. Ren, Z.; Ward, T.E.; Regan, J.M. Electricity production from cellulose in a microbial fuel cell using a defined binary culture. Environ. Sci. Technol. 2007, 41, 4781-4786. [CrossRef] [PubMed]

269. Kannaiah Goud, R.; Venkata Mohan, S. Pre-fermentation of waste as a strategy to enhance the performance of single chambered microbial fuel cell (MFC). Int. J. Hydrog. Energy 2011, 36, 13753-13762. [CrossRef]

270. Ishii, S.; Suzuki, S.; Norden-Krichmar, T.M.; Wu, A.; Yamanaka, Y.; Nealson, K.H.; Bretschger, O. Identifying the microbial communities and operational conditions for optimized wastewater treatment in microbial fuel cells. Water Res. 2013, 47, 7120-7130. [CrossRef]

271. Wrana, N.; Sparling, R.; Cicek, N.; Levin, D.B. Hydrogen gas production in a microbial electrolysis cell by electrohydrogenesis. J. Clean. Prod. 2010, 18. [CrossRef]

272. Rabaey, K.; Verstraete, W. Microbial fuel cells: Novel biotechnology for energy generation. Trends Biotechnol. 2005, 23, 291-298. [CrossRef] [PubMed]

273. Mohan, S.V.; Chandrasekhar, K. Solid phase microbial fuel cell (SMFC) for harnessing bioelectricity from composite food waste fermentation: Influence of electrode assembly and buffering capacity. Bioresour. Technol. 2011, 102, 7077-7085. [CrossRef] [PubMed]

274. Butti, S.K.; Velvizhi, G.; Sulonen, M.L.K.; Haavisto, J.M.; Oguz Koroglu, E.; Yusuf Cetinkaya, A.; Singh, S.; Arya, D.; Annie Modestra, J.; Vamsi Krishna, K.; et al. Microbial electrochemical technologies with the perspective of harnessing bioenergy: Maneuvering towards upscaling. Renew. Sustain. Energy Rev. 2016, 53, 462-476. [CrossRef]

275. Srikanth, S.; Venkata Mohan, S. Influence of terminal electron acceptor availability to the anodic oxidation on the electrogenic activity of microbial fuel cell (MFC). Bioresour. Technol. 2012, 123, 480-487. [CrossRef] [PubMed]

276. Xia, X.; Tokash, J.C.; Zhang, F.; Liang, P.; Huang, X.; Logan, B.E. Oxygen-reducing biocathodes operating with passive oxygen transfer in microbial fuel cells. Environ. Sci. Technol. 2013, 47, 2085-2091. [CrossRef]

277. Oh, S.E.; Logan, B.E. Hydrogen and electricity production from a food processing wastewater using fermentation and microbial fuel cell technologies. Water Res. 2005, 39, 4673-4682. [CrossRef]

278. Freguia, S.; Teh, E.H.; Boon, N.; Leung, K.M.; Keller, J.; Rabaey, K. Microbial fuel cells operating on mixed fatty acids. Bioresour. Technol. 2010, 101, 1233-1238. [CrossRef] [PubMed]

279. Mohanakrishna, G.; Venkata Mohan, S.; Sarma, P.N. Utilizing acid-rich effluents of fermentative hydrogen production process as substrate for harnessing bioelectricity: An integrative approach. Int. J. Hydrog. Energy 2010, 35, 3440-3449. [CrossRef] 
280. Nam, J.Y.; Kim, H.W.; Lim, K.H.; Shin, H.S. Effects of organic loading rates on the continuous electricity generation from fermented wastewater using a single-chamber microbial fuel cell. Bioresour. Technol. 2010, 101, S33-S37. [CrossRef]

281. Teng, S.X.; Tong, Z.H.; Li, W.W.; Wang, S.G.; Sheng, G.P.; Shi, X.Y.; Liu, X.W.; Yu, H.Q. Electricity generation from mixed volatile fatty acids using microbial fuel cells. Appl. Microbiol. Biotechnol. 2010, 87, 2365-2372. [CrossRef]

282. Choi, J.D.R.; Chang, H.N.; Han, J.I. Performance of microbial fuel cell with volatile fatty acids from food wastes. Biotechnol. Lett. 2011, 33, 705-714. [CrossRef]

283. Li, X.M.; Cheng, K.Y.; Wong, J.W.C. Bioelectricity production from food waste leachate using microbial fuel cells: Effect of NaCl and pH. Bioresour. Technol. 2013, 149, 452-458. [CrossRef]

284. Xu, S.Y.; Lam, H.P.; Karthikeyan, O.P.; Wong, J.W.C. Optimization of food waste hydrolysis in leach bed coupled with methanogenic reactor: Effect of $\mathrm{pH}$ and bulking agent. Bioresour. Technol. 2011, 102, 3702-3708. [CrossRef]

285. Logan, B.E. Chapter 3 Voltage Generation. In Microbial Fuel Cells; John Wiley \& Sons, Inc.: Hoboken, NJ, USA, 2008; ISBN 9780470258590.

286. Logan, B.E.; Hamelers, B.; Rozendal, R.; Schröder, U.; Keller, J.; Freguia, S.; Aelterman, P.; Verstraete, W.; Rabaey, K. Microbial fuel cells: Methodology and technology. Environ. Sci. Technol. 2006, 40, 5181-5192. [CrossRef]

287. Fan, Y.; Sharbrough, E.; Liu, H. Quantification of the internal resistance distribution of microbial fuel cells. Environ. Sci. Technol. 2008, 42, 8101-8107. [CrossRef]

288. Huang, J.; Sun, B.; Zhang, X. Electricity generation at high ionic strength in microbial fuel cell by a newly isolated Shewanella marisflavi EP1. Appl. Microbiol. Biotechnol. 2010, 85, 1141-1149. [CrossRef]

289. Lefebvre, O.; Tan, Z.; Kharkwal, S.; $\mathrm{Ng}$, H.Y. Effect of increasing anodic $\mathrm{NaCl}$ concentration on microbial fuel cell performance. Bioresour. Technol. 2012, 112, 336-340. [CrossRef] [PubMed]

290. Liu, H.; Cheng, S.; Logan, B.E. Production of electricity from acetate or butyrate using a single-chamber microbial fuel cell. Environ. Sci. Technol. 2005, 39, 658-662. [CrossRef] [PubMed]

291. He, Z.; Huang, Y.; Manohar, A.K.; Mansfeld, F. Effect of electrolyte pH on the rate of the anodic and cathodic reactions in an air-cathode microbial fuel cell. Bioelectrochemistry 2008, 74, 78-82. [CrossRef] [PubMed]

292. Raghavulu, S.V.; Mohan, S.V.; Goud, R.K.; Sarma, P.N. Effect of anodic pH microenvironment on microbial fuel cell (MFC) performance in concurrence with aerated and ferricyanide catholytes. Electrochem. Commun. 2009, 11, 371-375. [CrossRef]

293. Behera, M.; Jana, P.S.; More, T.T.; Ghangrekar, M.M. Rice mill wastewater treatment in microbial fuel cells fabricated using proton exchange membrane and earthen pot at different pH. Bioelectrochemistry 2010, 79, 228-233. [CrossRef]

294. Yuan, Y.; Zhao, B.; Zhou, S.; Zhong, S.; Zhuang, L. Electrocatalytic activity of anodic biofilm responses to $\mathrm{pH}$ changes in microbial fuel cells. Bioresour. Technol. 2011, 102, 6887-6891. [CrossRef] [PubMed]

295. Macoveanu, M.; Gavrilescu, M.; Gavrilescu, D. Energy from biomass in pulp and paper mills. Environ. Eng. Manag. J. 2008, 7, 537-546.

296. Sakai, M.; Seto, T.; Kaneko, M.; Hada, M.; Kinomoto, T. Method For Producing Pulp From. U.S. Patent 5500086, 19 March 1996.

297. Chao, K.P.; Su, Y.C.; Chen, C.S. Feasibility of utilizing Rhizoclonium in pulping and papermaking. J. Appl. Phycol. 2000, 12, 53-62. [CrossRef]

298. Ververis, C.; Georghiou, K.; Danielidis, D.; Hatzinikolaou, D.G.; Santas, P.; Santas, R.; Corleti, V. Cellulose, hemicelluloses, lignin and ash content of some organic materials and their suitability for use as paper pulp supplements. Bioresour. Technol. 2007, 98, 296-301. [CrossRef]

299. Sudhakar, M.P.; Kumar, B.R.; Mathimani, T.; Arunkumar, K. A review on bioenergy and bioactive compounds from microalgae and macroalgae-sustainable energy perspective. J. Clean. Prod. 2019, 228, 1320-1333. [CrossRef]

300. Ramana, K.V.; Xavier, J.R. Recent Trends in Pharmaceutical Biotechnology Abstract. iMedPub J. 2017, 1, 1-10.

301. Zhang, M.; Cui, S.W.; Cheung, P.C.K.; Wang, Q. Antitumor polysaccharides from mushrooms: A review on their isolation process, structural characteristics and antitumor activity. Trends Food Sci. Technol. 2007, 18, 4-19. [CrossRef]

302. Philippoussis, A.; Diamantopoulou, P.; Israilides, C. Productivity of agricultural residues used for the cultivation of the medicinal fungus Lentinula edodes. Int. Biodeterior. Biodegrad. 2007, 59, 216-219. [CrossRef]

303. Israilides, C.; Philippoussis, A. Bio-technologies of Recycling Agro-industrial Wastes for the Production of Commercially Important Fungal Polysaccharides and Mushrooms. Biotechnol. Genet. Eng. Rev. 2003, 20, 247-260. [CrossRef]

304. Subbarao, K.; Kuchibhotla, J.; Kakkar, V.V. Pyridoxal 5'-phosphate-A new physiological inhibitor of blood coagulation and platelet function. Biochem. Pharmacol. 1979, 28, 531-534. [CrossRef]

305. Borchers, A.T.; Stern, J.S.; Hackman, R.M.; Keen, C.L.; Gershwin, M.E. Minireview Mushrooms, Tumors, and Immunity. Proc. Soc. Exp. Biol. Med. 1999, 221, 281-293. [PubMed]

306. Yu, Y.; Shen, M.; Song, Q.; Xie, J. Biological activities and pharmaceutical applications of polysaccharide from natural resources: A review. Carbohydr. Polym. 2018, 183, 91-101. [CrossRef] [PubMed]

307. Chihara, G.; Hamuro, J.; Maeda, Y.Y.; Arai, Y.; Fukuoka, F. Fractionation and Purification of the Polysaccharides with Marked Antitumor Activity, Especially Lentinan, from Lentinus edodes (Berk.) Sing. (an Edible Mushroom). Cancer Res. 1970, 30, $2776-2781$. [PubMed]

308. Ren, G.; Xu, L.; Lu, T.; Yin, J. Structural characterization and antiviral activity of lentinan from Lentinus edodes mycelia against infectious hematopoietic necrosis virus. Int. J. Biol. Macromol. 2018, 115, 1202-1210. [CrossRef] 
309. Cooke, C.L.; Hyun, J.A.; Kim, J.; Solnick, J.V.; Lebrilla, C.B. Method for profiling mucin oligosaccharides from gastric biopsies of rhesus monkeys with and without Helicobacter pylori infection. Anal. Chem. 2007, 79, 8090-8097. [CrossRef]

310. Borchers, A.T.; Keen, C.L.; Gershwin, M.E. Mushrooms, Tumors, and Immunity: An Update. Exp. Biol. Med. 2004, $229,393-406$. [CrossRef]

311. Reis, F.S.; Martins, A.; Vasconcelos, M.H.; Morales, P.; Ferreira, I.C.F.R. Functional foods based on extracts or compounds derived from mushrooms. Trends Food Sci. Technol. 2017, 66, 48-62. [CrossRef]

312. Wasser, S. Medicinal mushrooms as a source of antitumor and immunomodulating polysaccharides. Appl. Microbiol. Biotechnol. 2002, 60, 258-274.

313. Liu, Q.; Duan, B.; Xu, X.; Zhang, L. Progress in rigid polysaccharide-based nanocomposites with therapeutic functions. J. Mater. Chem. B 2017, 5, 5690-5713. [CrossRef] [PubMed]

314. Ferreira, S.S.; Passos, C.P.; Madureira, P.; Vilanova, M.; Coimbra, M.A. Structure-function relationships of immunostimulatory polysaccharides: A review. Carbohydr. Polym. 2015, 132, 378-396. [CrossRef] [PubMed]

315. Venugopal, V.; Chawla, S.P.; Nair, P.M. Spray dried protein powder from threadfin bream: Preparation, properties and comparison with FPC type-B. J. Muscle Foods 1996, 7, 55-71. [CrossRef]

316. Craig, S.; College, V.; Medicine, V.; Tech, V. Understanding fish nutrition, feeds, and feeding. Virginia Coop Ext. 2017. Available online: https: / /vtechworks.lib.vt.edu/bitstream/handle/10919/80712/FST-269.pdf (accessed on 11 February 2021).

317. Benjakul, S.; Morrissey, M.T. Protein Hydrolysates from Pacific Whiting Solid Wastes. J. Agric. Food Chem. 1997, 45, 3423-3430. [CrossRef]

318. Yathisha, U.G.; Bhat, I.; Karunasagar, I.; Mamatha, B.S. Antihypertensive activity of fish protein hydrolysates and its peptides. Crit. Rev. Food Sci. Nutr. 2019, 59, 2363-2374. [CrossRef]

319. Rajapakse, N.; Jung, W.K.; Mendis, E.; Moon, S.H.; Kim, S.K. A novel anticoagulant purified from fish protein hydrolysate inhibits factor XIIa and platelet aggregation. Life Sci. 2005, 76, 2607-2619. [CrossRef]

320. Hajfathalian, M.; Ghelichi, S.; García-Moreno, P.J.; Moltke Sørensen, A.D.; Jacobsen, C. Peptides: Production, bioactivity, functionality, and applications. Crit. Rev. Food Sci. Nutr. 2018, 58, 3097-3129. [CrossRef]

321. Kim, S.K.; Kim, Y.T.; Byun, H.G.; Nam, K.S.; Joo, D.S.; Shahidi, F. Isolation and characterization of antioxidative peptides from gelatin hydrolysate of Alaska pollack skin. J. Agric. Food Chem. 2001, 49, 1984-1989. [CrossRef]

322. Mendis, E.; Rajapakse, N.; Byun, H.G.; Kim, S.K. Investigation of jumbo squid (Dosidicus gigas) skin gelatin peptides for their in vitro antioxidant effects. Life Sci. 2005, 77, 2166-2178. [CrossRef]

323. Pal, G.K.; Suresh, P.V. Sustainable valorisation of seafood by-products: Recovery of collagen and development of collagen-based novel functional food ingredients. Innov. Food Sci. Emerg. Technol. 2016, 37, 201-215. [CrossRef]

324. Cheung, R.C.F.; Ng, T.B.; Wong, J.H. Marine peptides: Bioactivities and applications. Mar. Drugs 2015, 13, 4006-4043. [CrossRef] [PubMed]

325. Sato, H.; Kitazawa, H.; Adachi, I.; Horikoshi, I. Microdialysis assessment of microfibrous collagen containing a P-glycoproteinmediated transport inhibitor, cyclosporine A, for local delivery of etoposide. Pharm. Res. 1996, 13, 1565-1569. [CrossRef] [PubMed]

326. Aytekin, A.O.; Morimura, S.; Kida, K. Synthesis of chitosan-caffeic acid derivatives and evaluation of their antioxidant activities. J. Biosci. Bioeng. 2011, 111, 212-216. [CrossRef] [PubMed]

327. Guo, Z.; Xing, R.; Liu, S.; Zhong, Z.; Li, P. Synthesis and hydroxyl radicals scavenging activity of quaternized carboxymethyl chitosan. Carbohydr. Polym. 2008, 73, 173-177. [CrossRef]

328. Zhong, Z.; Ji, X.; Xing, R.; Liu, S.; Guo, Z.; Chen, X.; Li, P. The preparation and antioxidant activity of the sulfanilamide derivatives of chitosan and chitosan sulfates. Bioorganic Med. Chem. 2007, 15, 3775-3782. [CrossRef]

329. Rabea, E.I.; Badawy, M.E.T.; Stevens, C.V.; Smagghe, G.; Steurbaut, W. Chitosan as antimicrobial agent: Applications and mode of action. Biomacromolecules 2003, 4, 1457-1465. [CrossRef]

330. Yusof, N.L.B.M.; Wee, A.; Lim, L.Y.; Khor, E. Flexible chitin films as potential wound-dressing materials: Wound model studies. J. Biomed. Mater. Res. Part. A 2003, 66, 224-232. [CrossRef]

331. Hassan, S.A.; Al-Sabagh, A.M.; Shalaby, N.H.; Hanafi, S.A.; Hassan, H.A. Various characteristics of multi-modified rice husk silica-anchored Ni or Pt nanoparticles as swift catalytic systems in some petrochemical processes. Rev. Mex. Urol. 2016, 76, 484-495. [CrossRef]

332. Harish, B.S.; Uppuluri, K.B.; Anbazhagan, V. Synthesis of fibrinolytic active silver nanoparticle using wheat bran xylan as a reducing and stabilizing agent. Carbohydr. Polym. 2015, 132, 104-110. [CrossRef]

333. Patel, K.G.; Misra, N.M.; Vekariya, R.H.; Shettigar, R.R. One-pot multicomponent synthesis in aqueous medium of 1,4dihydropyrano [2,3-c]pyrazole-5-carbonitrile and derivatives using a green and reusable nano-SiO2catalyst from agricultural waste. Res. Chem. Intermed. 2018, 44, 289-304. [CrossRef]

334. Fang, K.; Chen, J.; Zhou, X.; Mei, C.; Tian, Q.; Xu, J.; Wong, C.P. Decorating biomass-derived porous carbon with Fe2O3 ultrathin film for high-performance supercapacitors. Electrochim. Acta 2018, 261, 198-205. [CrossRef]

335. Devi, L.L.; Basavapoornima, C.; Venkatramu, V.; Babu, P.; Jayasankar, C.K. Synthesis of Ca2SiO4:Dy3+ phosphors from agricultural waste for solid state lighting applications. Ceram. Int. 2017, 43, 16622-16627. [CrossRef]

336. Pandit, P.R.; Fulekar, M.H. Egg shell waste as heterogeneous nanocatalyst for biodiesel production: Optimized by response surface methodology. J. Environ. Manag. 2017, 198, 319-329. [CrossRef] 
337. Yan, D.; Zhang, H.; Chen, L.; Zhu, G.; Wang, Z.; Xu, H.; Yu, A. Supercapacitive properties of Mn3O4 nanoparticles bio-synthesized from banana peel extract. RSC Adv. 2014, 4, 23649-23652. [CrossRef]

338. Ali, S.M. Fabrication of a nanocomposite from an agricultural waste and its application as a biosorbent for organic pollutants. Int. J. Environ. Sci. Technol. 2018, 15, 1169-1178. [CrossRef]

339. Adoki, A. Factors affecting yeast growth and protein yield production from orange, plantain and banana wastes processing residues using Candida sp. Afr. J. Biotechnol. 2008, 7, 290-295.

340. Yabaya, A.; Ado, S.A. Mycelial protein production by Aspergillus niger using banana peels. World 2008, 3, 9-12. [CrossRef]

341. Lenihan, P.; Orozco, A.; O’Neill, E.; Ahmad, M.N.M.; Rooney, D.W.; Walker, G.M. Dilute acid hydrolysis of lignocellulosic biomass. Chem. Eng. J. 2010, 156, 395-403. [CrossRef]

342. Kaparaju, P.; Serrano, M.; Thomsen, A.B.; Kongjan, P.; Angelidaki, I. Bioethanol, biohydrogen and biogas production from wheat straw in a biorefinery concept. Bioresour. Technol. 2009, 100, 2562-2568. [CrossRef]

343. Zhang, Y.; Chen, X.; Gu, Y.; Zhou, X. A physicochemical method for increasing methane production from rice straw: Extrusion combined with alkali pretreatment. Appl. Energy 2015, 160, 39-48. [CrossRef]

344. Zheng, L.; Zheng, P.; Sun, Z.; Bai, Y.; Wang, J.; Guo, X. Production of vanillin from waste residue of rice bran oil by Aspergillus niger and Pycnoporus cinnabarinus. Bioresour. Technol. 2007, 98, 1115-1119. [CrossRef] [PubMed]

345. Rózsenberszki, T.; Koók, L.; Hutvágner, D.; Nemestóthy, N.; Bélafi-Bakó, K.; Bakonyi, P.; Kurdi, R.; Sarkady, A. Comparison of anaerobic degradation processes for bioenergy generation from liquid fraction of pressed solid waste. Waste Biomass Valoriz. 2015, 6, 465-473. [CrossRef]

346. Koók, L.; Rózsenberszki, T.; Nemestóthy, N.; Bélafi-Bakó, K.; Bakonyi, P. Bioelectrochemical treatment of municipal waste liquor in microbial fuel cells for energy valorization. J. Clean. Prod. 2016, 112, 4406-4412. [CrossRef]

347. Scarlat, N.; Dallemand, J.F.; Monforti-Ferrario, F.; Nita, V. The role of biomass and bioenergy in a future bioeconomy: Policies and facts. Environ. Dev. 2015, 15, 3-34. [CrossRef]

348. Imbert, E. Food waste valorization options: Opportunities from the bioeconomy. Open Agric. 2017, 2, 195-204. [CrossRef]

349. Rodas-Zuluaga, L.I.; Castañeda-Hernández, L.; Castillo-Vacas, E.I.; Gradiz-Menjivar, A.; López-Pacheco, I.Y.; Castillo-Zacarías, C.; Iqbal, H.M.N.; Parra-Saldivar, R. Bio-capture and influence of $\mathrm{CO}_{2}$ on the growth rate and biomass composition of the microalgae Botryococcus braunii and Scenedesmus sp. J. $\mathrm{CO}_{2}$ Util. 2021, 43, 101371. [CrossRef]

350. Scarlat, N.; Dallemand, J.F.; Banja, M. Possible impact of 2020 bioenergy targets on European Union land use. A scenario-based assessment from national renewable energy action plans proposals. Renew. Sustain. Energy Rev. 2013, 18, 595-606. [CrossRef]

351. Eickhout, B.B.; Gjaltema, J.; de Jong, F. A strategy for a bio-based economy. Green New Deal Ser. 2012, 9, 1-52.

352. Lin, J.; Zuo, J.; Gan, L.; Li, P.; Liu, F.; Wang, K.; Chen, L.; Gan, H. Effects of mixture ratio on anaerobic co-digestion with fruit and vegetable waste and food waste of China. J. Environ. Sci. 2011, 23, 1403-1408. [CrossRef]

353. Kretschmer, B.; Smith, C.; Watkins, E.; Allen, B.; Buckwell, A.; Desbarats, J.; Kieve, D. Technology options for feeding 10 billion people. Recycling agricultural, forestry \& food wastes and residues for sustainable bioenergy and biomaterials. Food Eng. 2013, 1-149. [CrossRef]

354. De Besi, M.; McCormick, K. Towards a bioeconomy in Europe: National, regional and industrial strategies. Sustainability 2015, 7, 10461-10478. [CrossRef]

355. Azar, C.; Lindgren, K.; Andersson, B.A. Global energy scenarios meeting stringent $\mathrm{CO}_{2}$ constraints-Cost-effective fuel choices in the transportation sector. Energy Policy 2003, 31, 961-976. [CrossRef] 